\title{
Health and Safety Research Division Manual for the X-Ray Facility in Building 2008
}

\author{
P. S. Stansbury
}

OAK RIDGE NATIONAL LABORATORY OPERATED BY UNION CARBIDE CORPORATION · FOR THE DEPARTMENT OF ENERGY 


\section{DISCLAIMER}

This report was prepared as an account of work sponsored by an agency of the United States Government. Neither the United States Government nor any agency Thereof, nor any of their employees, makes any warranty, express or implied, or assumes any legal liability or responsibility for the accuracy, completeness, or usefulness of any information, apparatus, product, or process disclosed, or represents that its use would not infringe privately owned rights. Reference herein to any specific commercial product, process, or service by trade name, trademark, manufacturer, or otherwise does not necessarily constitute or imply its endorsement, recommendation, or favoring by the United States Government or any agency thereof. The views and opinions of authors expressed herein do not necessarily state or reflect those of the United States Government or any agency thereof. 


\section{DISCLAIMER}

Portions of this document may be illegible in electronic image products. Images are produced from the best available original document. 


\section{Printed in the United States of America. Available from National Technical Information Service}

U.S. Department of Commerce 5285 Port Royal Road, Springfield, Virginia 22161

Price: Printed Copy $\$ 6.00$; Microfiche $\$ 3.00$

This report was prepared as an account of work sponsored by an agency of the United States Government. Neither the United States Government nor any agency thereof, nor any of their employees, contractors, subcontractors, or their employees, makes any warranty, express or implied, nor assumes any legal liability or responsibility for any third party's use or the results of such use of any information, apparatus, product or process disclosed in this report, nor represents that its use by such third party would not infringe privately owned rights. 
Contract No. W-7405-eng-26

HEALTH AND SAFETY RESEARCH DIVISION

MANUAL FOR THE X-RAY FACILITY IN BUILDING 2008

P. S. Stansbury

Date Published: November 1977

NOTICE This document contains information of a preliminary nature. It is subject to revision or correction and therefore does not represent a final report.

This report NOTICE

This prepared as an account of work the United States Government. Neither the Energy States nor the United States Department of contractors, subcontractors, or thets, nor any of their any warranty, express or implied, or asployees, makes liability or responsibility for the accurses any legal or usefulness of any infor the accuracy, completenets proces dieclosed, or information, appanatus, product or infringe privately or represents that its use would not

OAK RIDGE NATIONAL LABORATORY

Oak Ridge, Tennessee 37830

operated by

UNION CARBIDE CORPORATION

for the

DEPARTMENT OF ENERGY 
THIS PAGE

\section{WAS INTENTIONALLY LEFT BLANK}




\section{TABLE OF CONTENTS}

Page

OVERVIEW AND PERFORMANCE CHARACTERISTICS .......... 1

DESCRIPTION OF X-RAY MACHINE ............ 10

HEALTH PHYSICS AND SAFETY FEATURES .............. 30

Radiation Safety Devices .............. 30

Radiation Safety Policy and Procedures ......... . 39

Additinnal Safety Policy and Equipment . . . . . . . . 41

Summary of Health Physics and Safety Policy

for the X-ray Facility in Building $2008 \ldots \ldots$

OPERATING INSTRUCTIONS .................... 45

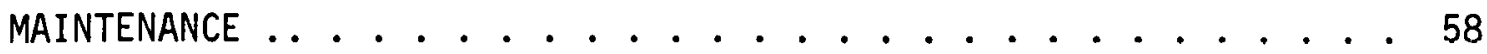

APPENDIX I

Annual Inspection Checklist............ 61 
THIS PAGE

\section{WAS INTENTIONALLY LEFT BLANK}




\section{LIST OF FIGURES}

Figure

1. Exposure rate at a target-to-detector distance of $100 \mathrm{~cm}$ as a function of generating potential . . . . . . 2

2. Normalized exposure rate as a function of tube current (error bars correspond to $\pm 2 \%$ plus the least significant digit uncertainty) . . . . . . . . 3

3. X-ray machine output spectrum measured with a $\mathrm{Ge}(\mathrm{Li})$ detector-- $60 \mathrm{kVCp}$............. 5

4. X-ray machine output spectrum measured with a $\mathrm{Ge}(\mathrm{L} i)$ detector-- $80 \mathrm{kVcp}$............. 6

5. X-ray machine output spectrum measured with a $\mathrm{Ge}(\mathrm{Li})$ detector-- $100 \mathrm{kVcp}$............ 7

6. Floor plan for the X-ray facility . . . . . . . . 9

7. Tube stand and tubehead ............... . . 11

8. $0 i 1$ cooler and tubestand transformer . . . . . . . 12

9. H.V. $\tan k$................. 13

10. Control panel (overall view) ............. 14

11. H.V. control console . . . . . . . . . . . . 15

12. Interlock control panel . . . . . . . . . . . 16

13. Auxillaries control panel .............. 17

14. Filament regulator panel . . . . . . . . . . 18

15. Integrator . . . . . . . . . . . . . . 19

16. Radiation monitors .............. 20

17. Chirper checker ................ . . 21

18. X-ray machine schematic ... . . . . . . . . 25

19. Power distribution and logic schematic . . . . . . . . 27

20. Interlock system schematic . . . . . . . . . . 32 


\section{OVERVIEW AND PERFORMANCE CHARACTERISTICS}

The facility in the east end of Building 2008 consists of an $x$-ray machine and a shielded enclosure. The $x$-ray machine is of the constant potential type and can be operated continuously at generating potentials up to $125 \mathrm{kVcp}$ with tube currents ranging from $0.1 \mu \mathrm{A}$ to $10 \mathrm{~mA}$. Both the generating potential and the tube current are highiy regulated and stabilized. The machine is installed and operated within a large shielded enclosure. In addition to the $x$-ray machine and its ancillary equipment, the shielded enclosure contains many of the features of a general chemistry and physics laboratory including work benches, sinks, storage space, and electrical and gas service.

The $x$-ray machine has two operating ranges. On the low range it can be operated at generating potentials up to $75 \mathrm{kVCp}$ with tube currents up to $20 \mathrm{~mA}$. On high range it can be operated between 75 to $125 \mathrm{kVcp}$ with tube currents up to $10 \mathrm{~mA}$. Due to the $x$-ray machine's unique configuration, it can be operated on either range with excellent stability and regulation as low as $0.1 \mu \mathrm{A}$. At any point within its range, the $\mathrm{x}$-ray machine can be operated continuously for an indefinite period of time.

The exposure rate, the output spectra, and the generating potential have been carefully measured and calibrated. The exposure rate was measured with a calibrated ionization chamber and electrometer dosimetry system (Victoreen Radocon III). The normalized exposure rate as a function of generating potential is shown in Figure 1 . The reference line with a slope of 2.0 shows how the $x$-ray machine's output varies as a function of the square of the generating potential. Figure 2 shows the 


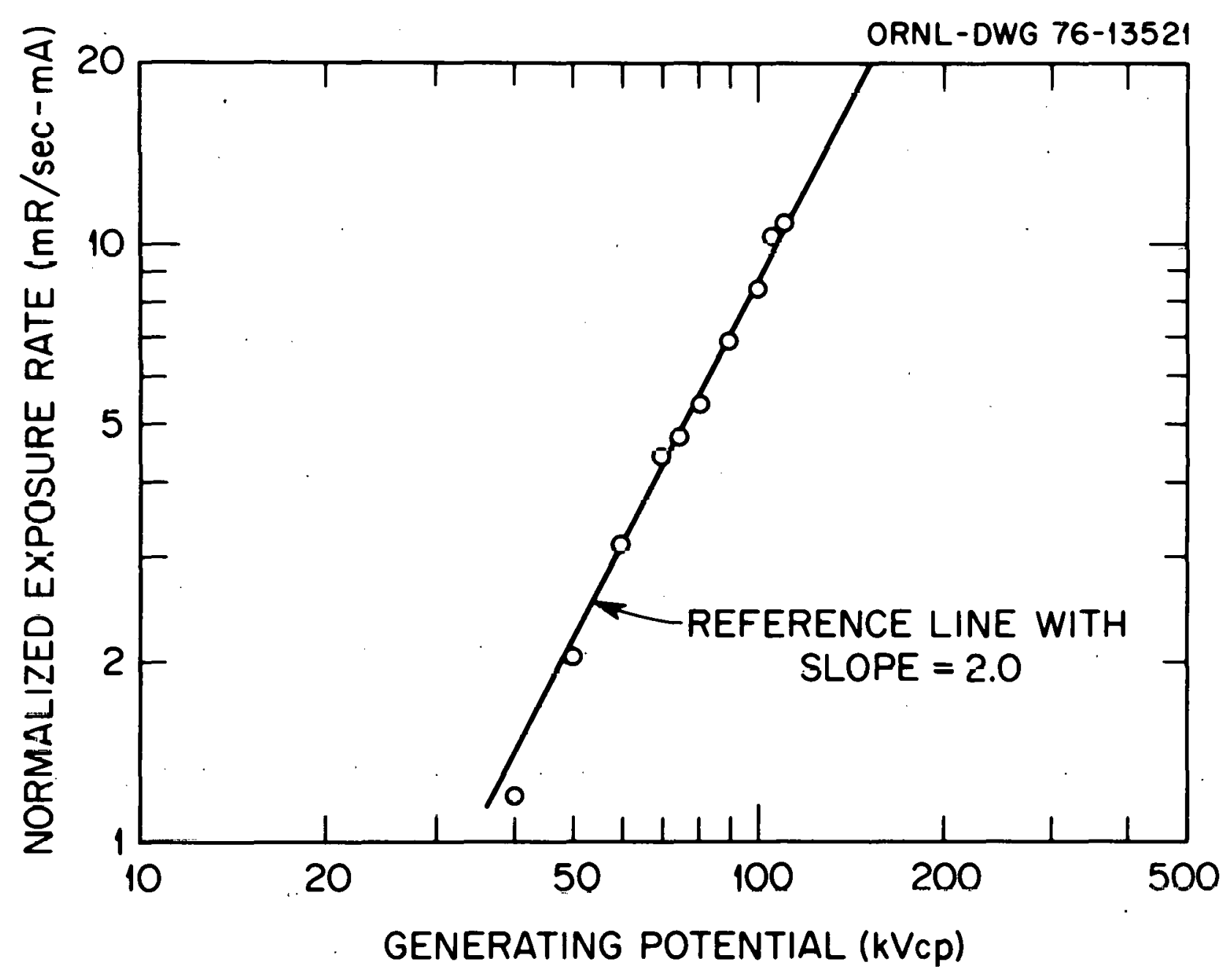

Fig. 1. Exposure rate at a target-to-detector distance of $100 \mathrm{~cm}$ as a function of generating potential. 


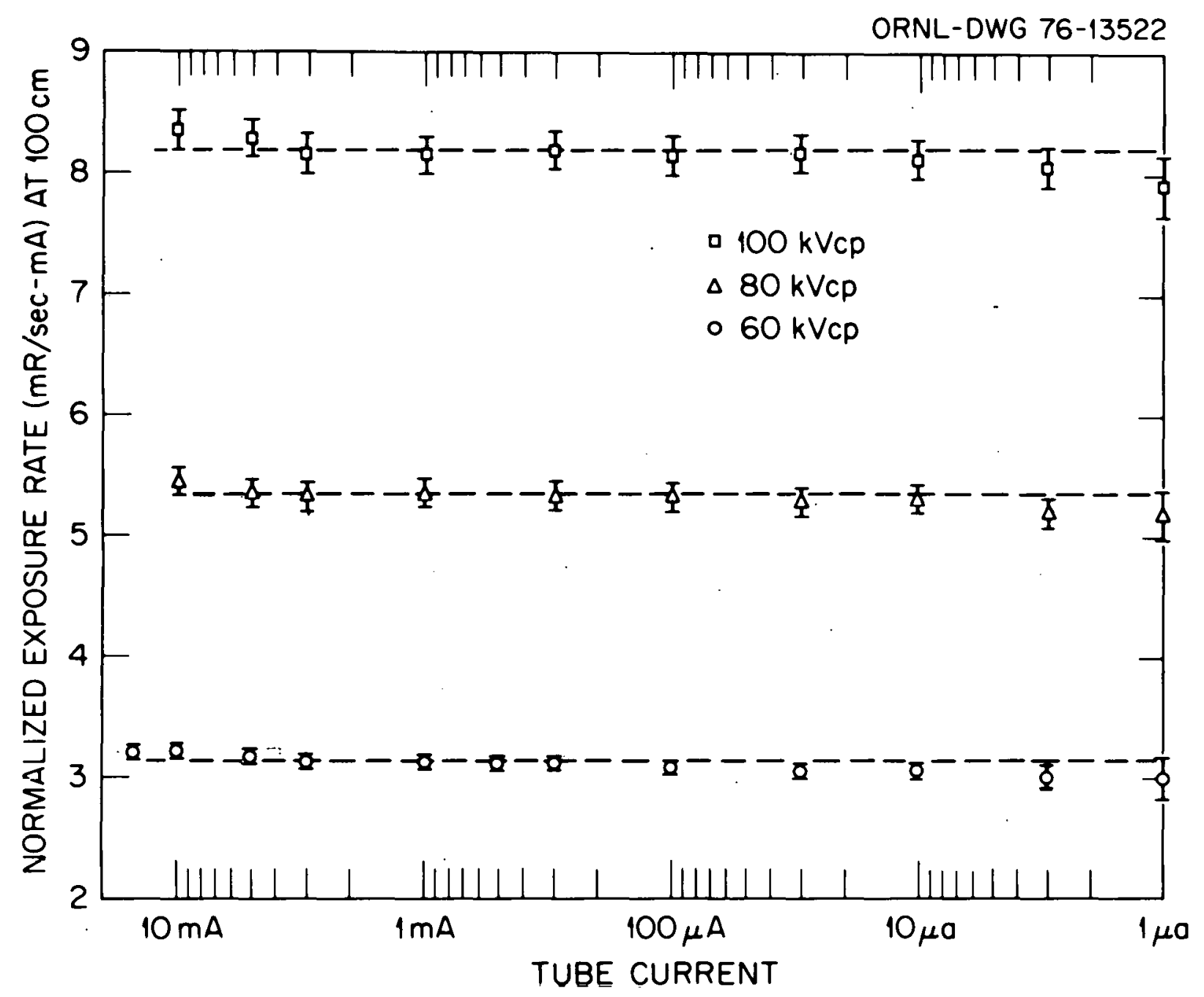

Fig. 2. Normalized exposure rate as a function of tube current (error bars correspond to $\pm 2 \%$ plus the least significant digit uncertainty). 
normalized exposure rate vs. tube current. The horizontal, dashed lines show the linearity of response of the $x$-ray machine over a variation of tube current of four orders of magnitude.

The energy distribution of the output spectrum of the $x$-ray machine was measured with a high resolution detector. $A \mathrm{Ge}(\mathrm{L} i)$ detector, with a thin beryllium window, was positioned in the center of the beam $3 \mathrm{~m}$ from the $x$-ray tube focal spot. An adjustable pinhole collimator, placed directly in front of the detector, and a low tube current $(\sim 1 \mu \mathrm{A})$ were employed to limit the count rate to a level that would not degrade the performance of the detector. The full-width-at-half-maximum (FWHM) resoTution of the detector was $0.9 \mathrm{keV}$ at $60 \mathrm{keV}$. Figures 3, 4, and 5 give the raw spectral data for generating potentials of 60,80 , and $100 \mathrm{kVcp}$. In addition, the raw data were grouped into "bins" $2 \mathrm{keV}$ wide and were corrected for efficiency losses. The "binned" data are presented also. The discontinuity in all three spectra at $37 \mathrm{keV}$ is due to the barium contained in the glass envelope of the $x$-ray tube.

I he accuracy, stability, and ripple of the generating potential were checked. The accuracy of the generating potential was determined in two ways. The upper end-points of the bremsstrahlung spectra, acquired as . described above, were determined by extrapolation. Also the generating potential was determined directly with a calibrated, temperature compensated voltage divider. Both methods indicated that the actual generating potential was within $\pm 0.5 \%$ of the indicated voltage. During initial testing of the high voltage transformer, the high voltage ripple was observed with an oscilloscope. The ripple was less than $0.1 \%$ peak-to-peak and was on the order of $0.04 \%$ rms. 


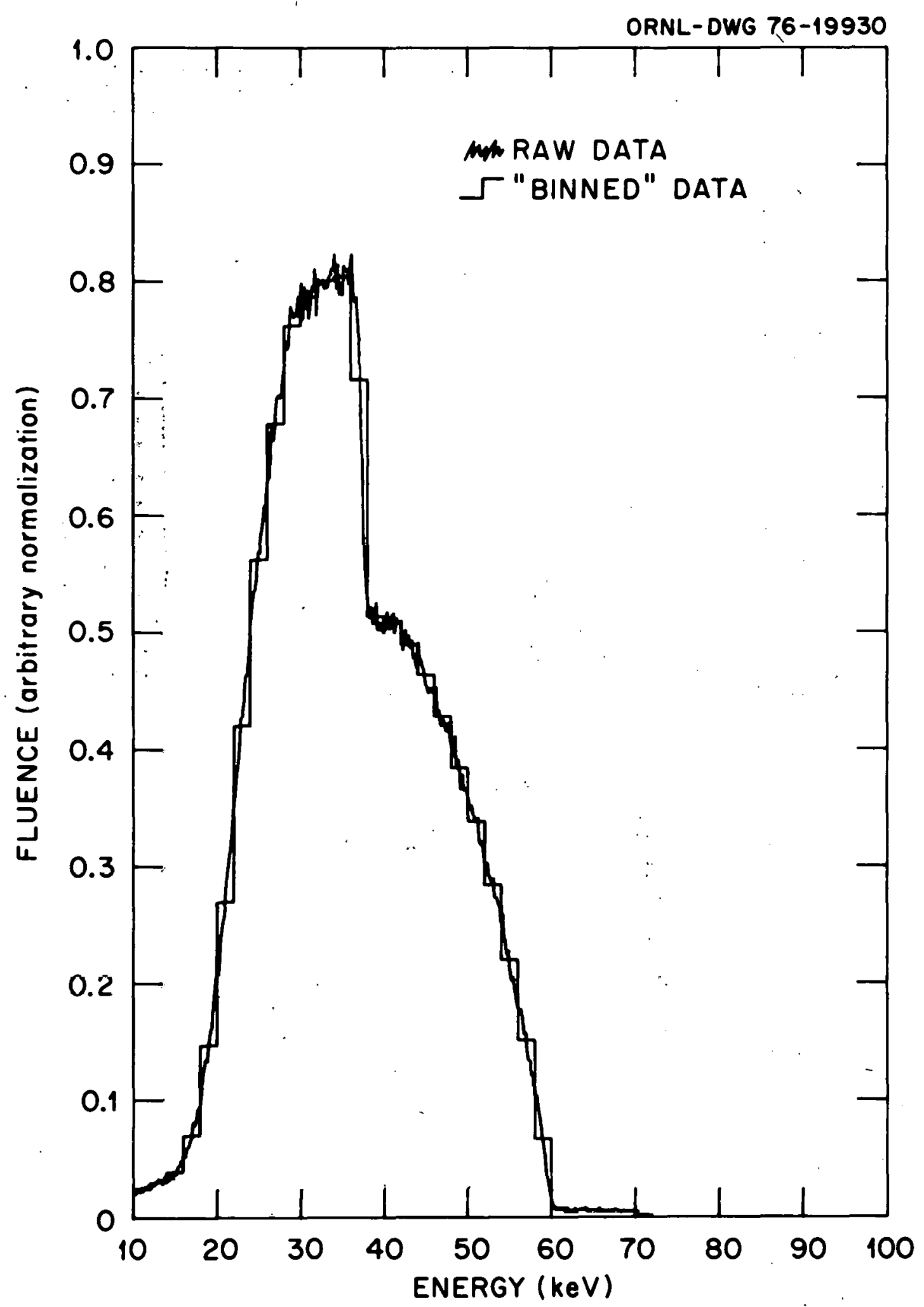

Fig. 3. X-ray machine output spectrum measured with a $\mathrm{Ge}(\mathrm{Li})$ detector-- $60 \mathrm{kVcp}$. 


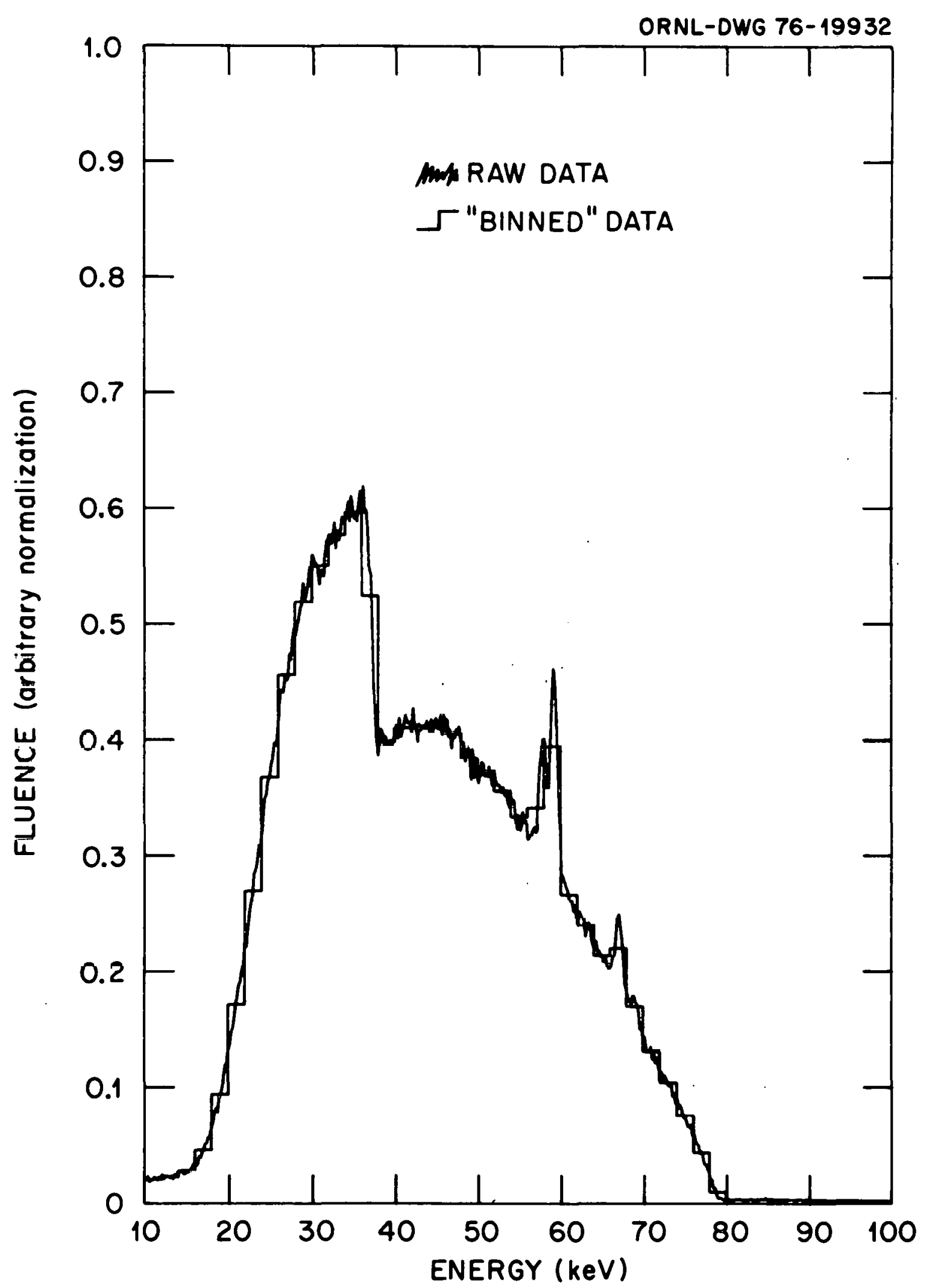

Fig. 4. X-ray machine output spectrum measured with a Ge(Li) detector-- $80 \mathrm{kV} \mathrm{cp}$. 


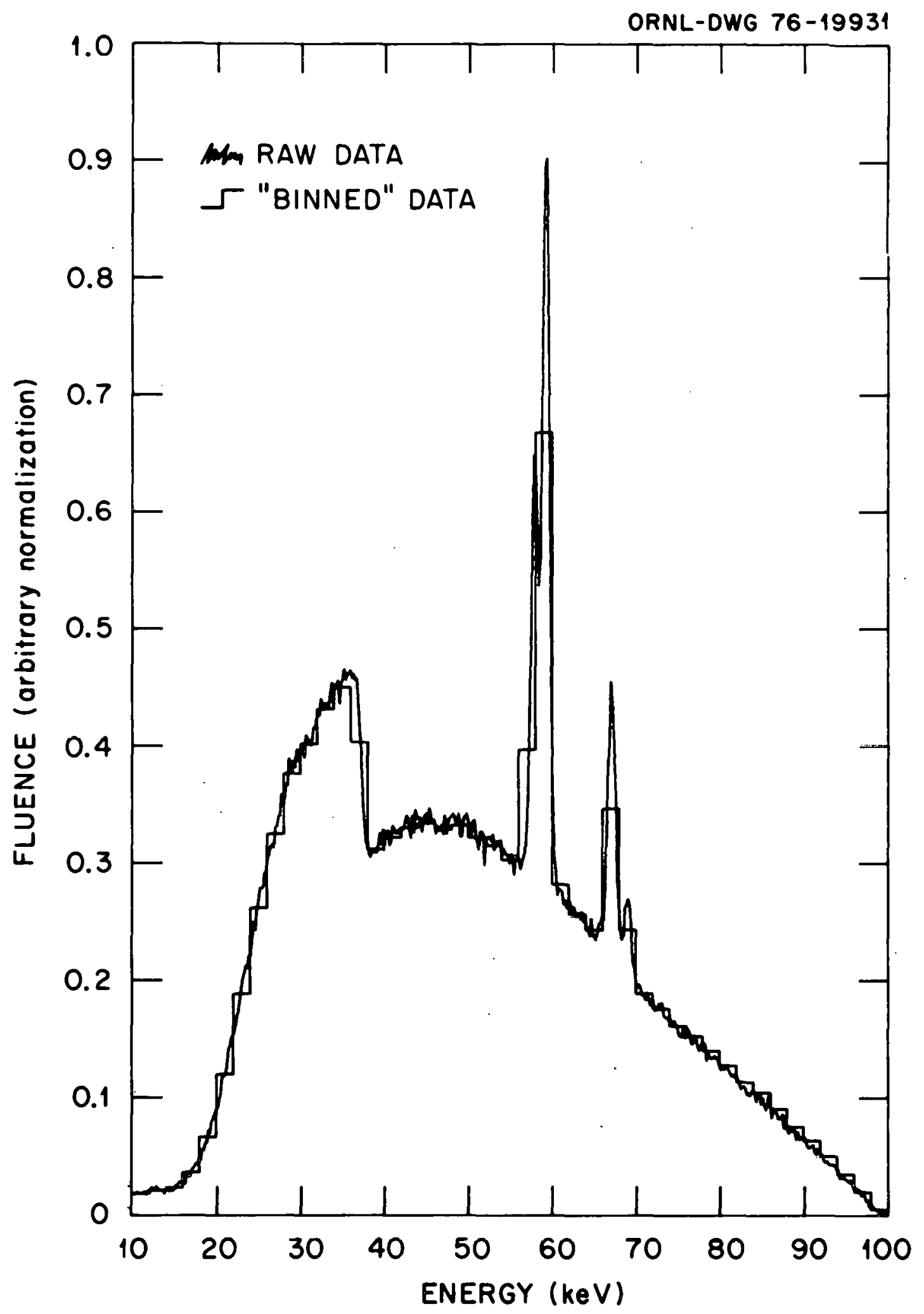

Fig. 5. X-ray machine output spectrum measured with a $\mathrm{Ge}(\mathrm{Li})$ detector-- $100 \mathrm{kVcp}$. 
The $x$-ray machine is housed in a large, walk-in vault (see figure 6). The primary shield is 16 inches of normal-density solid concrete block. The secondary shield is 8 inches of solid concrete block. The door in the secondary shield contains $1 / 8$ inch of lead. The lead overlapping between the primary shield (outside the building) and the secondary shield inside the building is $1 / 8$ inch thich. In addition to the $x$-ray machine, the shielded enclosure contains lab benches, sinks, storage space, and air, gas, water, and electricity service outlets. Just outside the shielded enclosure is a general purpose, vented hood. Electric service includes regular $110 \mathrm{~V}$ outlets, $220 \mathrm{~V}$ single-phase, $220 \mathrm{~V}$ threephase, and a heavy duty safety ground, separate from the building ground. The shielded enclosure also contains a storage area for intermediate level isotopic sources. This storage area, the shielding, and the general laboratory features make the facility suitable for a wide variety of dosimetry experiments. In particular, the facility has accommodated several programs of experiments involving in-phantom dosimetry. Absorbed dose distributions in fluid-filled phantoms have been determined for a variety of exposure configurations including external beams of $x$ rays and internal radioactive sources. 
ORNL-DWG 74-5133

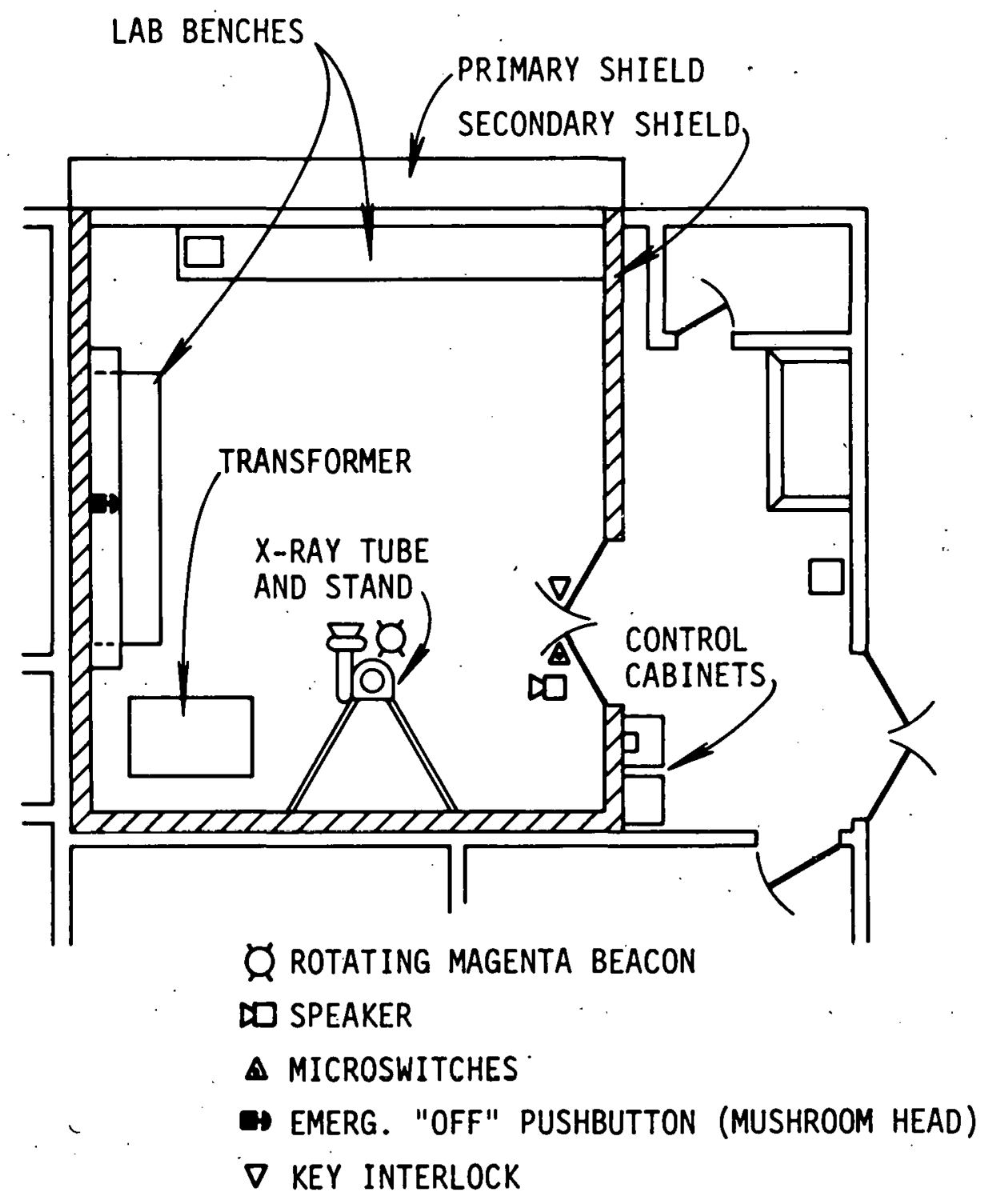

INTERIOR $20^{\prime} \times 20^{\prime}$

PRIMARY SHIELD $16^{\prime \prime}$ CONCRETE

SECONDARY SHIELD 8" CONCRETE OR 1/8" Pb

Fig. 6. Floor Plan for the $x$-ray facility. 


\section{DESCRIPTION OF X-RAY MACHINE}

The components of the $x$-ray machine include parts of a therapy-type medical $x$-ray machine, a regulated high voltage generator, and a filament regulator designed and fabricated at ORNL. : The $x$-ray tube, tube shield, collimator, tube stand, and oil cooler were parts of a Siemens $250 \mathrm{kV}$ therapy $x$-ray machine. The generating potential is produced by a series. tube requilated high voltage suppily manufactured by Universal Voltronics Corporation. The filament regulator is of a unique design, and it employs a Kepco DC power supply. A Brookhaven Instruments Corporation integrator is used to measure the tube current and to act as a timer. All of the interconnecting wiring and logic circuitry were fabricated at ORNL. Figures 7 through 17 identify the components described above and some of the components of the safety interlock system.

The $x$-ray tube is a 250-kV bipolar therapy x-ray tube (Siemens list number 640116). It is a hooded anode tube with an $0.8 \mathrm{~cm} \times 0.8 \mathrm{~cm}$ focal spot. It is encased in a glass envelope with no special window. The tube shield is rated also for $250 \mathrm{kV}$, and the tube envelope and tube shield have a combined inherent filtration of approximately $2 \mathrm{~mm}$ of aluminum equivalent. A therapy-type collimator is mounted on the tube shield aperture. Alternatively an assortment of therapy treatment cones may be used in place of the collimator. The therapy collimator is equipped with a light localizer. The accuracy of the light localizer was checked, and it indicates the size of the beam to within $\pm 0.3 \mathrm{~cm}$ at a distance of $1 \mathrm{~m}$ from the focal spot. A $5-\mathrm{m}$ flexible tape is mounted on a plate that temporarily attaches to the front of the collimator. As determined by 


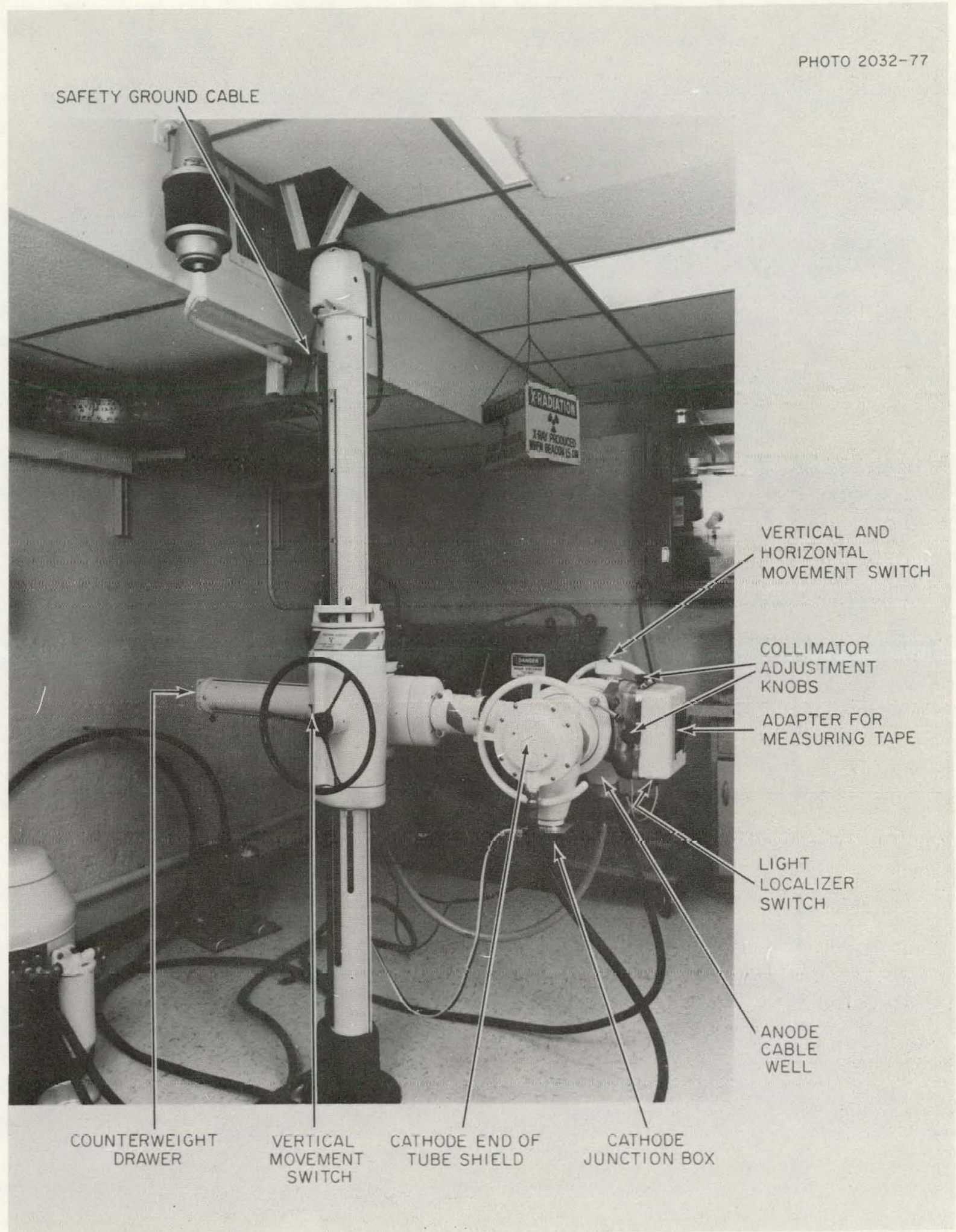

Fig. 7. Tubestand and tubehead. 
PHOTO NO. $2028-77$

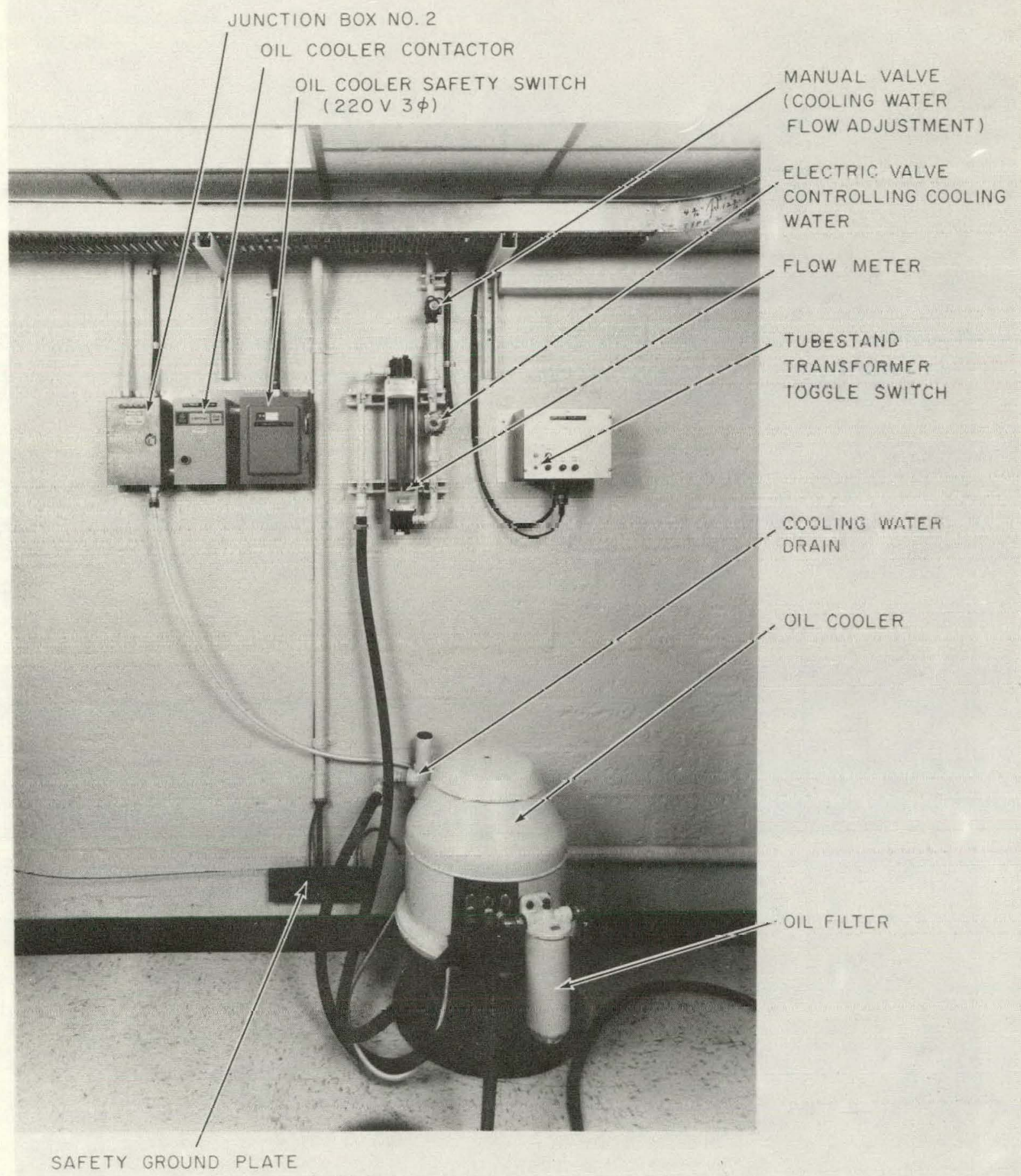

Fig. 8. $0 i 1$ cooler and tubestand transformer. 


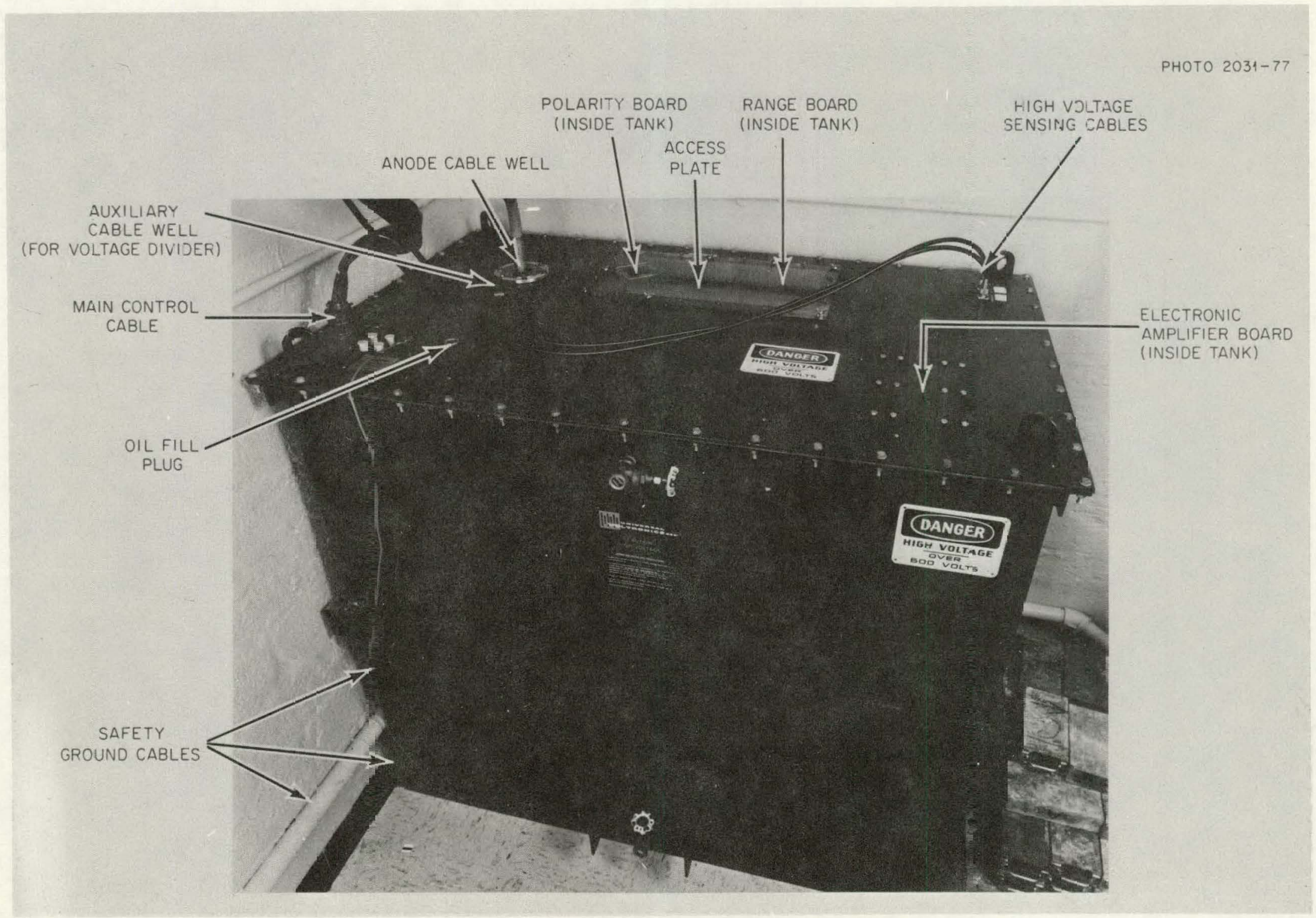

$\vec{\omega}$

Fig. 9. H.V. tank. 


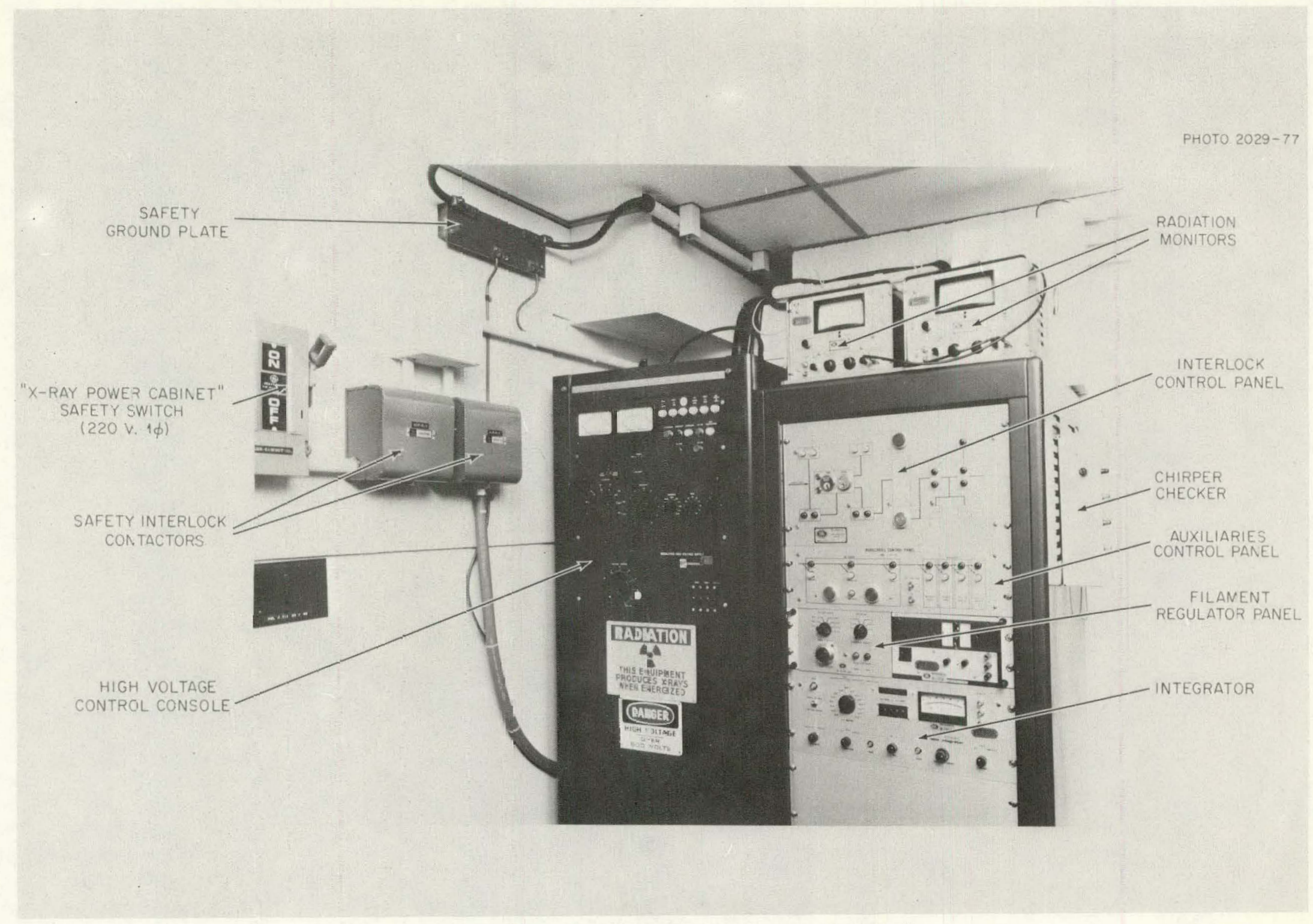

Fig. 10. Control panel (overall view). 


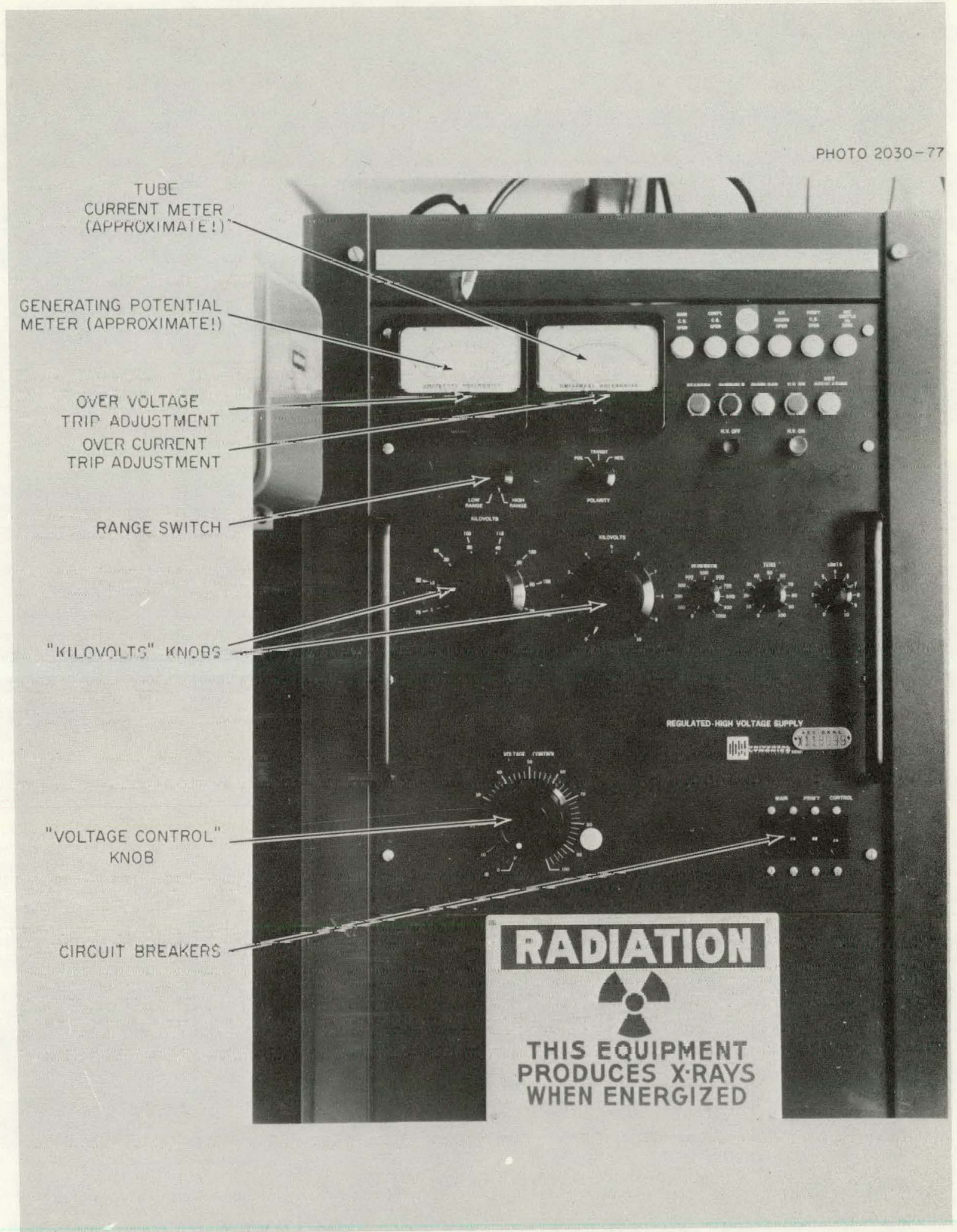

Fig. 11. H.V. control console. 


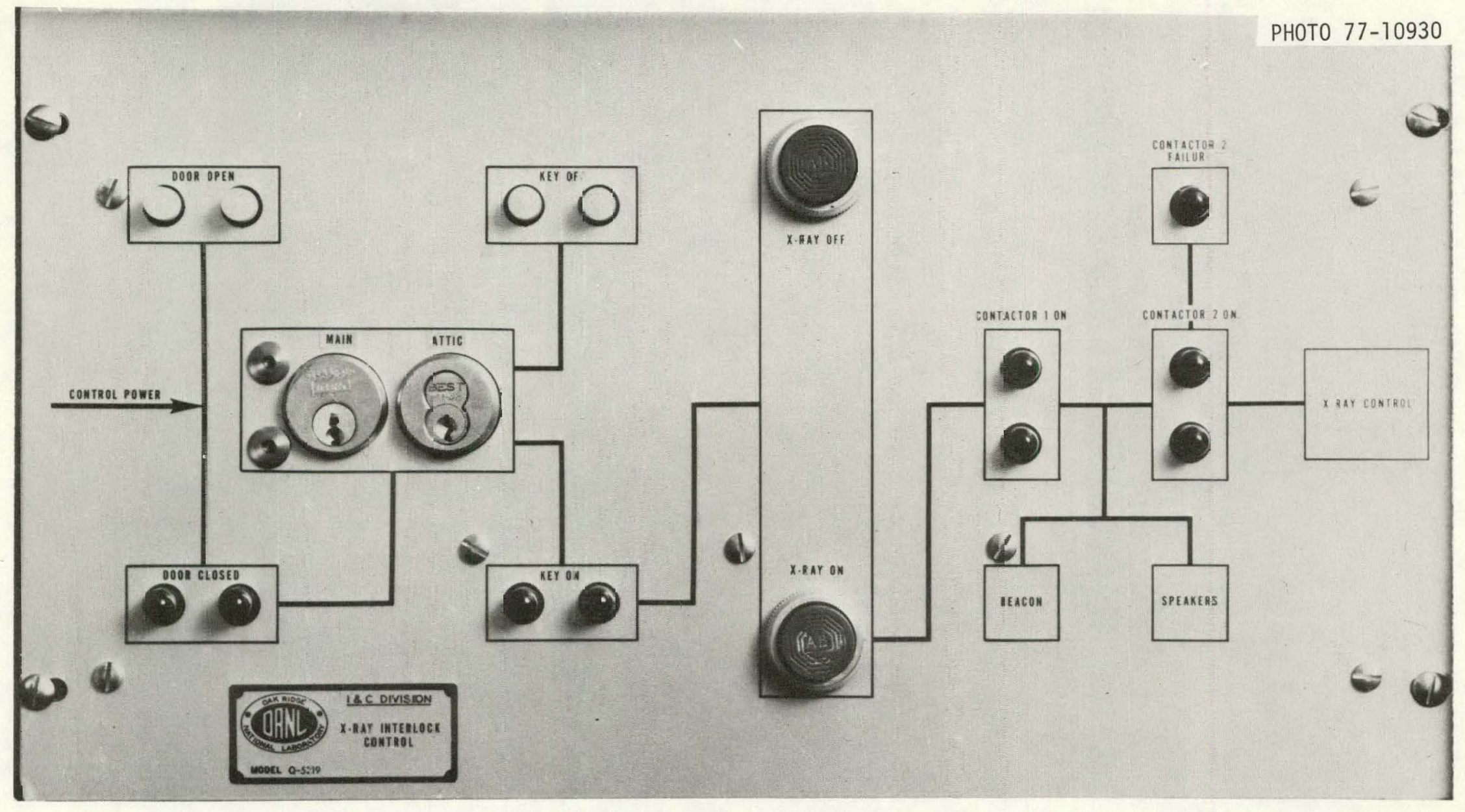

Fig. '2. Irterlock control panel. 


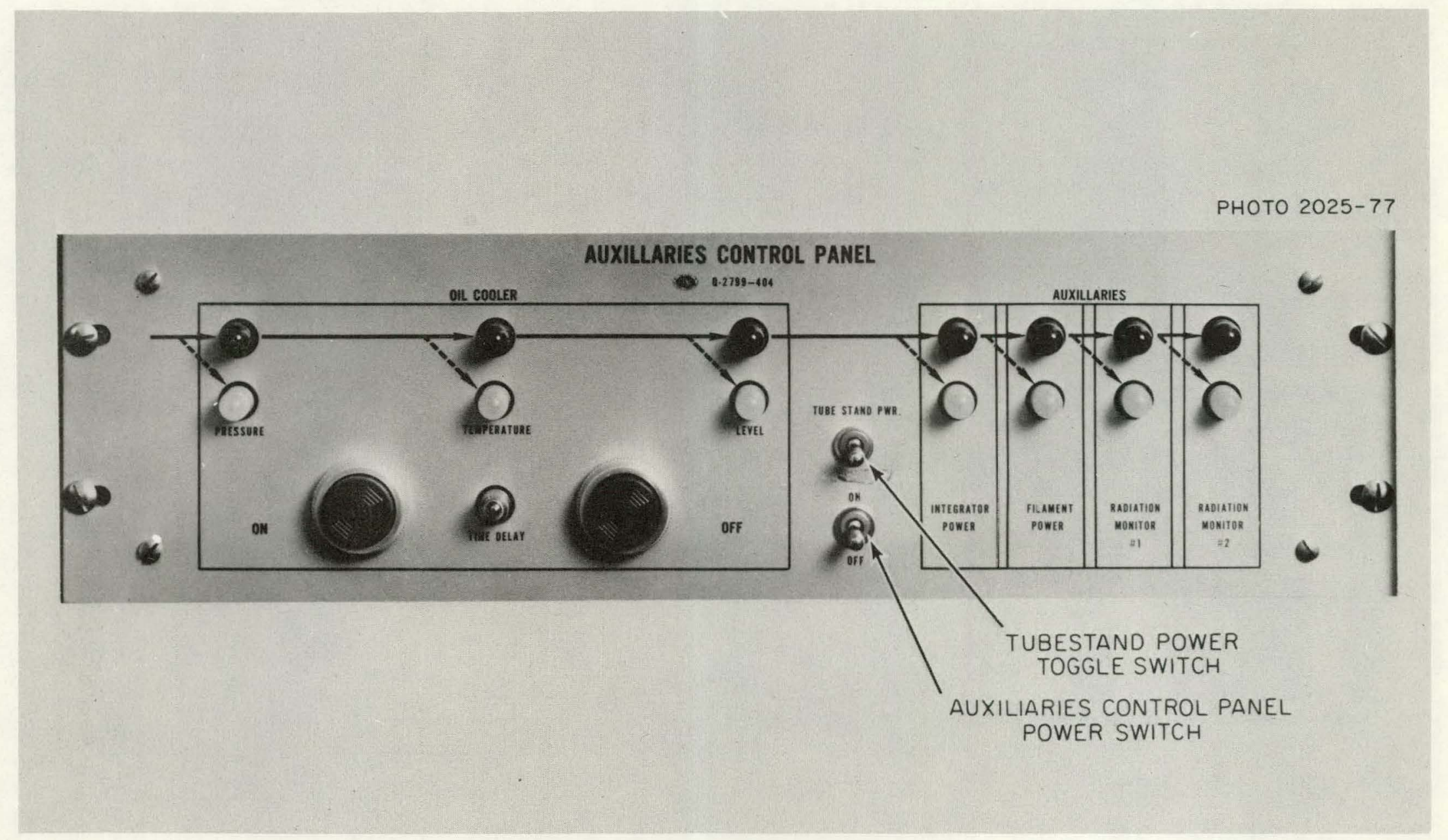

Fig. 13. Auxillaries control panel. 


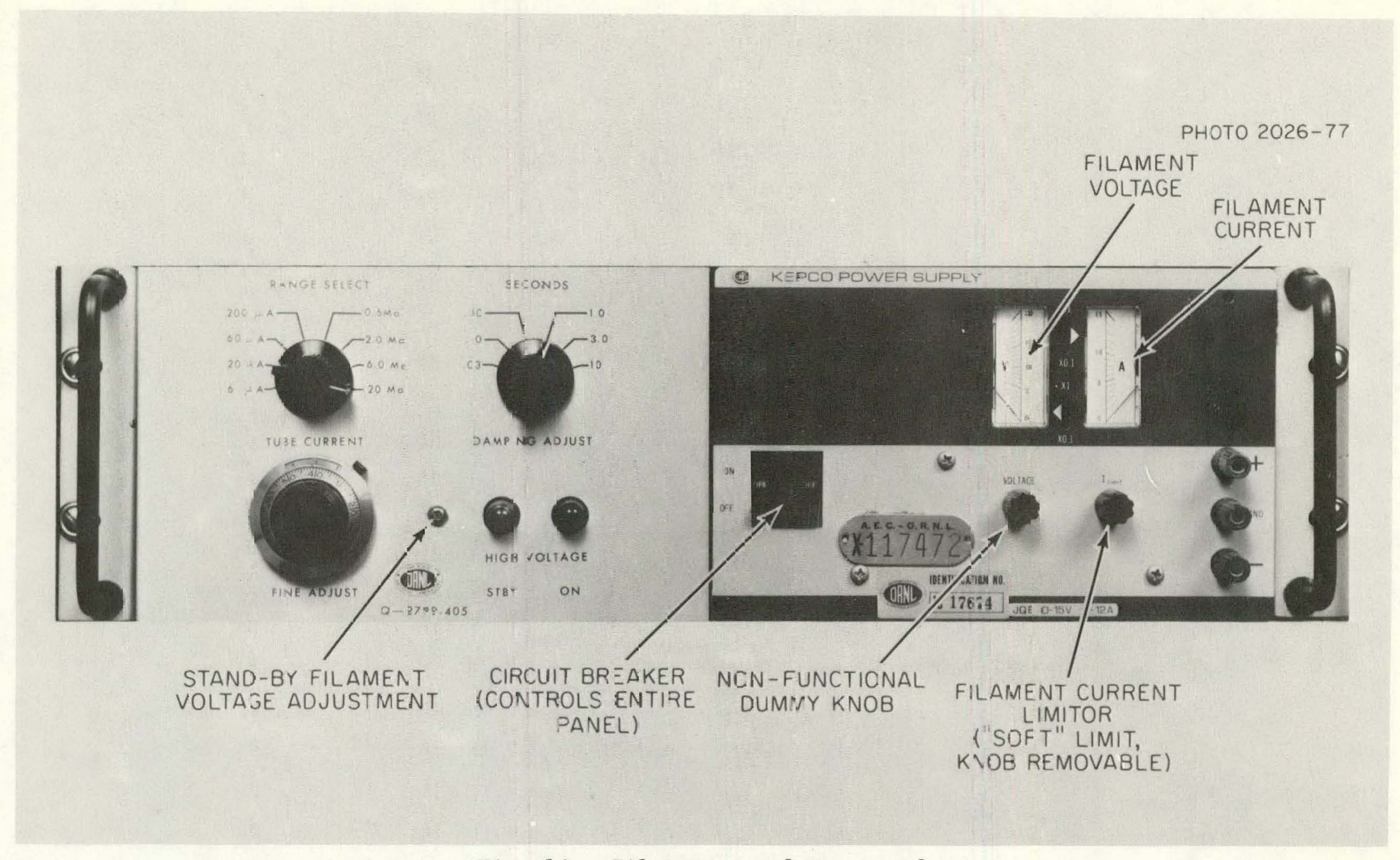

Fig. 14. Filanent regulator panel. 


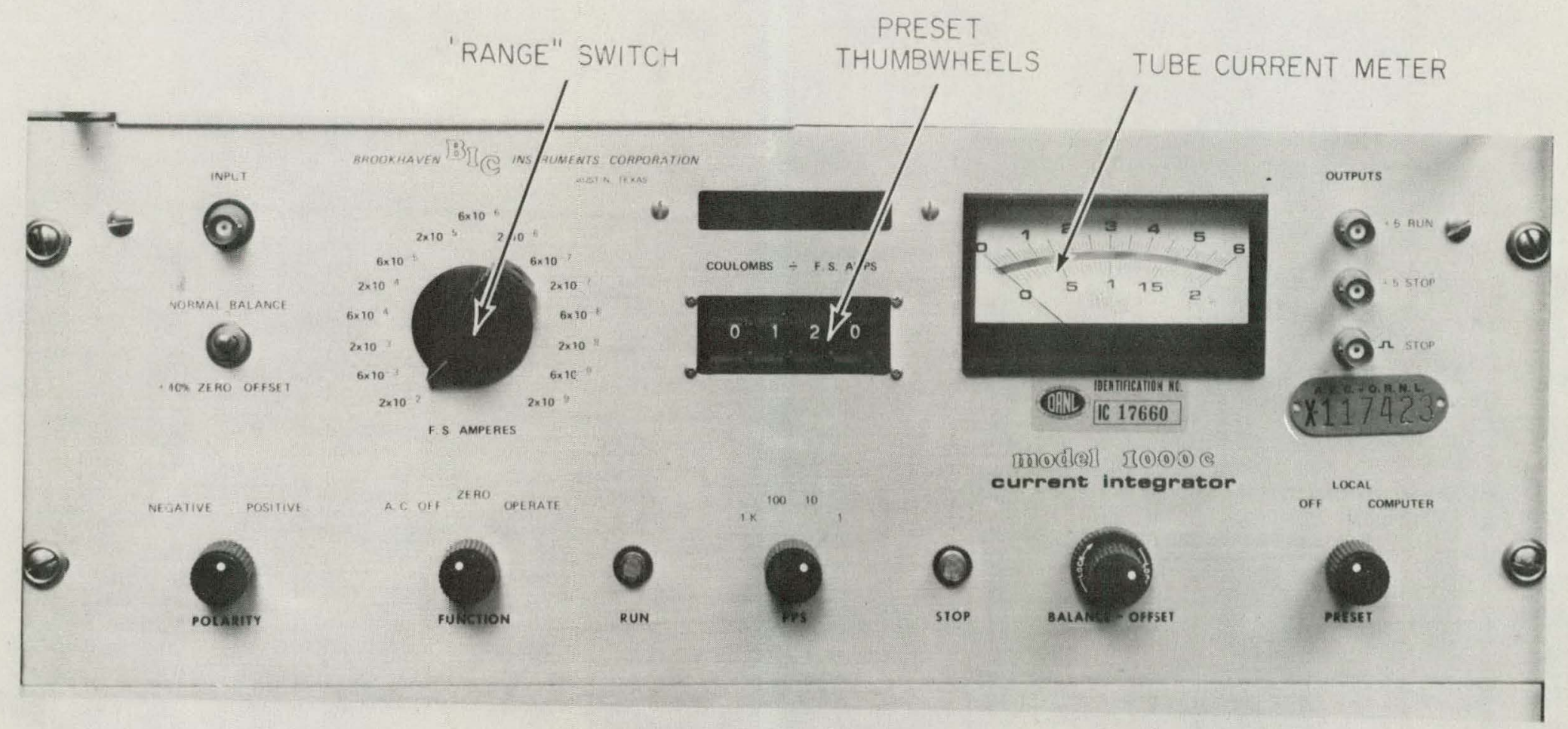

Fig. 15. Integrator. 


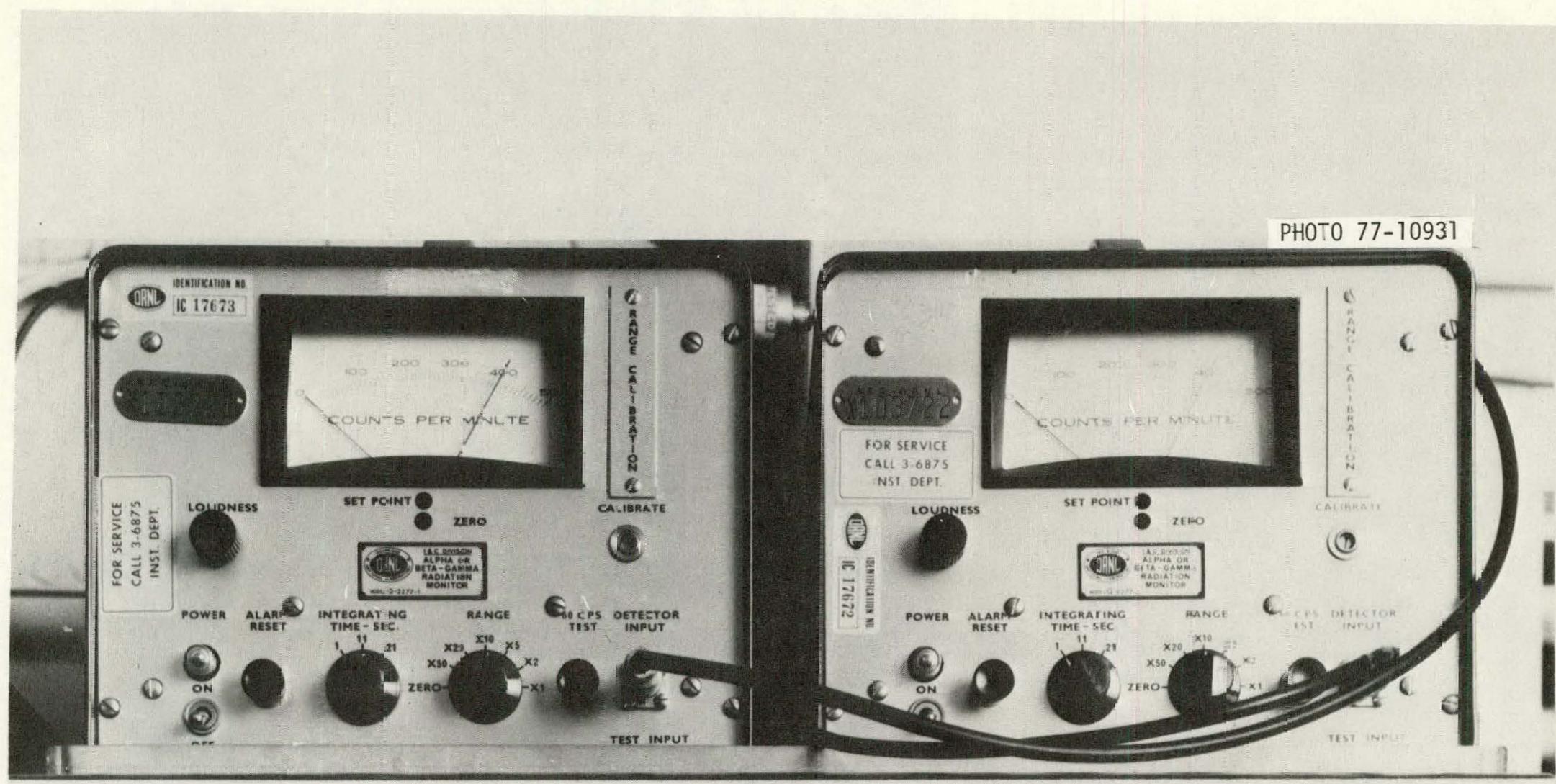




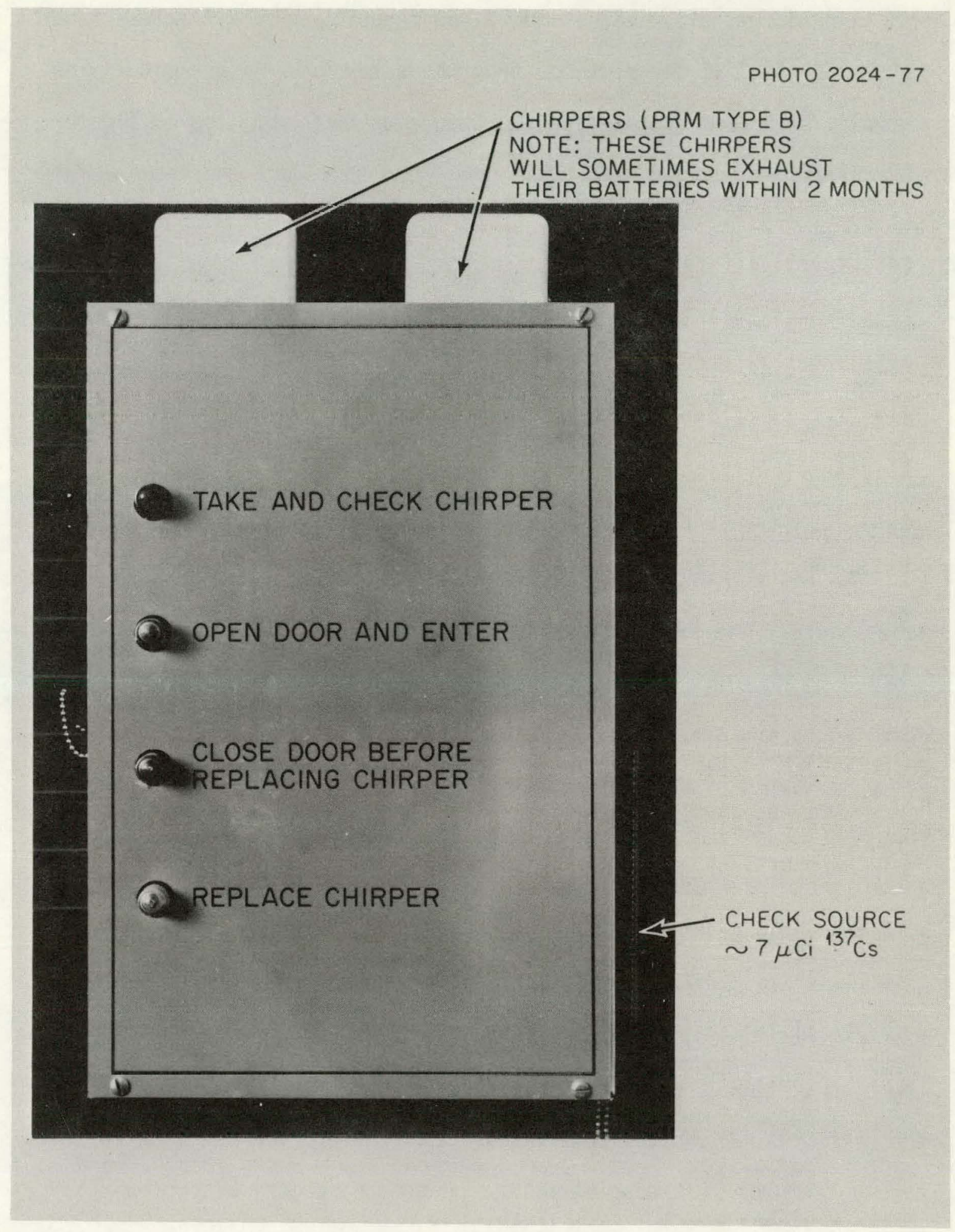

Fig. 17. Chirper checker. 
both mensuration and inverse square law techniques, the flexible tape is positioned so that the distance from the $x$-ray tube focal spot is the distance indicated by the flexible tape plus $35.0 \mathrm{~cm}$. The collimator housing was enshrouded with additional lead to reduce the leakage from the collimator to near zero.

The $x$-ray tube, tube housing, and collimator are supported by a therapy-type tube stand. The tube stand has electromagnetic locks to control movement. The switch on the upright controls vertical motion; the switch on the tube shield controls both horizontal and vertical motion. A drawer in the back end of the horizontal arm contains lead counter weights.

The oil cooler removes heat from the oil that circulates through the tube shield. The process water that carries away the waste heat is controlled by an electric valve and a manual valve. The electric valve is operated by the same circuitry that powers the oil cooler. The manual valve is used to control the process water flow rate. The oil cooler supplies cooled oil (indicated by red color-coding on the hose) to the anode end of the tube shield and the green color-coded hose returns oil from the cathode side of the tube shield. The oil cooler is equipped with pressure, level, and temperature safety switches which detect improper conditions. Improper oil level and oil temperature will disable the high voltage transformer. Lack of oil pressure will shut off both the high voltage and the power to the oil cooler. In addition to the safety features just described, the control circuitry also provides a cool-down period before the oil cooler is turned off. Depressing the oil cooler off button will cause the circulating pump and water flow to stop three to five minutes afterwards. 
The high voltage supplỳ that provides the generating potential for the $x$-ray machine has two components. The high voltage tank is located in the southwest corner of the $x$-ray room. The high voltage control console is beside the main control. console. The high voltage tank and control console are interconnected by a control cable and by two high voltage sensing cables. The output of the high voltage supply (positive DC voltage) is carried from the tank to the anode end of the tube shield with a Siemens high voltage cable. In addition, another cable well is built into the high voltage tank to allow connection of a voltage divider in parallel with the x-ray tube.

The high voltage supply employs a series regulator tube. In this scheme the transformers and capacitors within the high voltage tank generate an unregulated high voltage that is approximately $20 \%$ in excess of the desired voltage. The unregulated voltage is sensed by a resistor chain inside the tank. Based on the sensed voltage, amplifier circuitry continuously adjusts the voltage drop through the regulator tube such that the voltage produced is the one desired. The accuracy and ripple were discussed previously. The manufacturer claims that the high voltage supply will provide $0.1 \%$ regulation for any variation of load between no load and full load and for 1 ine voltage variations of $\pm 15 \%$. These aspects of the high voltage supply have not been checked directly, but, at this time, there is no reason to believe that the manufacturer's claims are not accurate.

The high voltage supply operates in one of two transformer configurations. In the parallel configuration (low range) up to $20 \mathrm{~mA}$ can be supplied at voltages up to $75 \mathrm{kVcp}$. In the series configuration (high 
range) up to $10 \mathrm{~mA}$ can be supplied at voltages between 75 and $125 \mathrm{kVcp}$. Changing of ranges is accomplished by using the proper plug-in "board" within the high voltage tank. The range switch on the control console affects only the regulating circuitry and the voltmeter. A plug-in "board" also changes the polarity of the output; however, positive polarity must be used to run the $x$-ray machine.

The fildillent regulator was designed and bufltat-ORNL. Figure 18 is a schematic diagram of the $x$-ray machine. Tube current regulation is achieved as follows. The tube current flows from the high voltage supply through the $x$-ray tube, through $R 1$, and through the integrator to ground. The input of the integrator is at virtual ground potential. The voltage developed across RI is in direct proportion to the tube current. Operational amplifier Ul compares the voltage across $R I$ with the voltage supplied by the reference voltage supply and the 10 turn pot. The output of operational amplifier UT is damped by operational amplifier U2 and its R-C circuitry and controls the output voltage of the filament power supply. Changing the output voltage of the filament power supply changes the emissivity of the filament and the flow of tube current through the $x-r a y$ tube. The damping provided by $U 2$ is necessary to keep the relatively fast operational amplifier circuitry from over-regulating the slower filament. Resistors:R1 and $R 2$ are discretely variable from $30 \Omega$ to $100 k \Omega$ in eight logarithmically spaced steps and are used to select the general range of tube current. The 10 turn pot provides fine adjustment capability. The integrator measures the tube current and can be used as a timer. This unique regulation scheme is made feasible by having the cathode at near ground potential. 
ORNL-DWG 76-7755

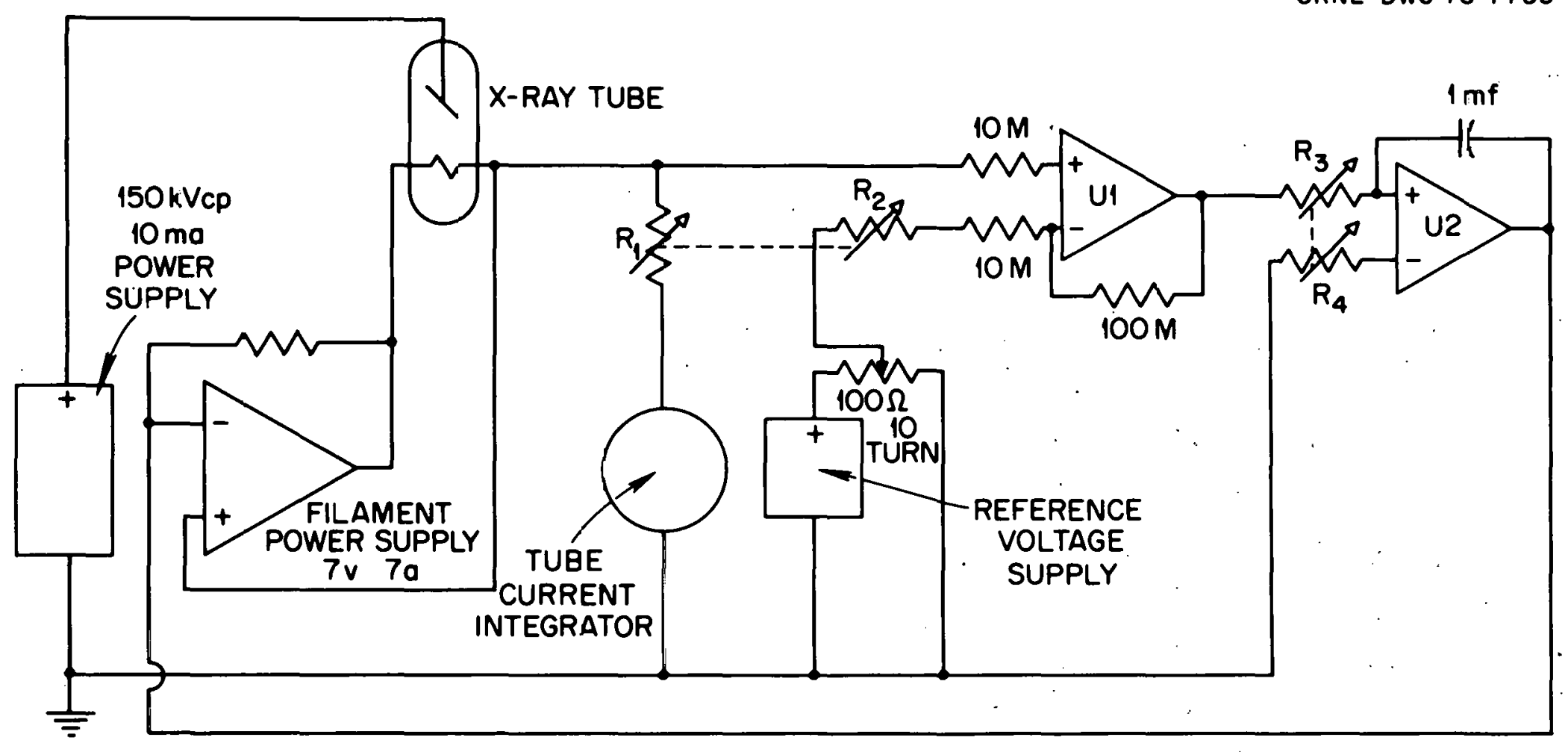

Fig. 18. X-ray machine schematic. 
In addition to the filament regulator, two other pieces of control circuitry were fabricated at ORNL. The safety interlock system, which will be discussed in the next section, controls the $220 \mathrm{~V}$ line power going to the high voltage supply. The Auxillaries Control Panel is the other major piece of control panel. The Auxillaries Control Panel operates the oil cooler and distributes power to the tube stand transformer. The panel enables and disables the functioning of the high voltage supply. The circuitry of the Auxillaries control Panel ensures that the oil cooler is on and operating properly and that the filament regulator, integrator, and both radiation monitors are turned on. If one of the auxillary devices mentioned is not turned on or if the oil cooler is not functioning properly, the Auxillaries Control Panel disables the high voltage supply.

Figure 19 is a schematic of the power distribution to the various components of the $x$-ray machine and its ancillary equipment. It also shows schematically the logic circuitry among the various components. For further details the engineering drawings referenced by figure 19 should be consulted. 


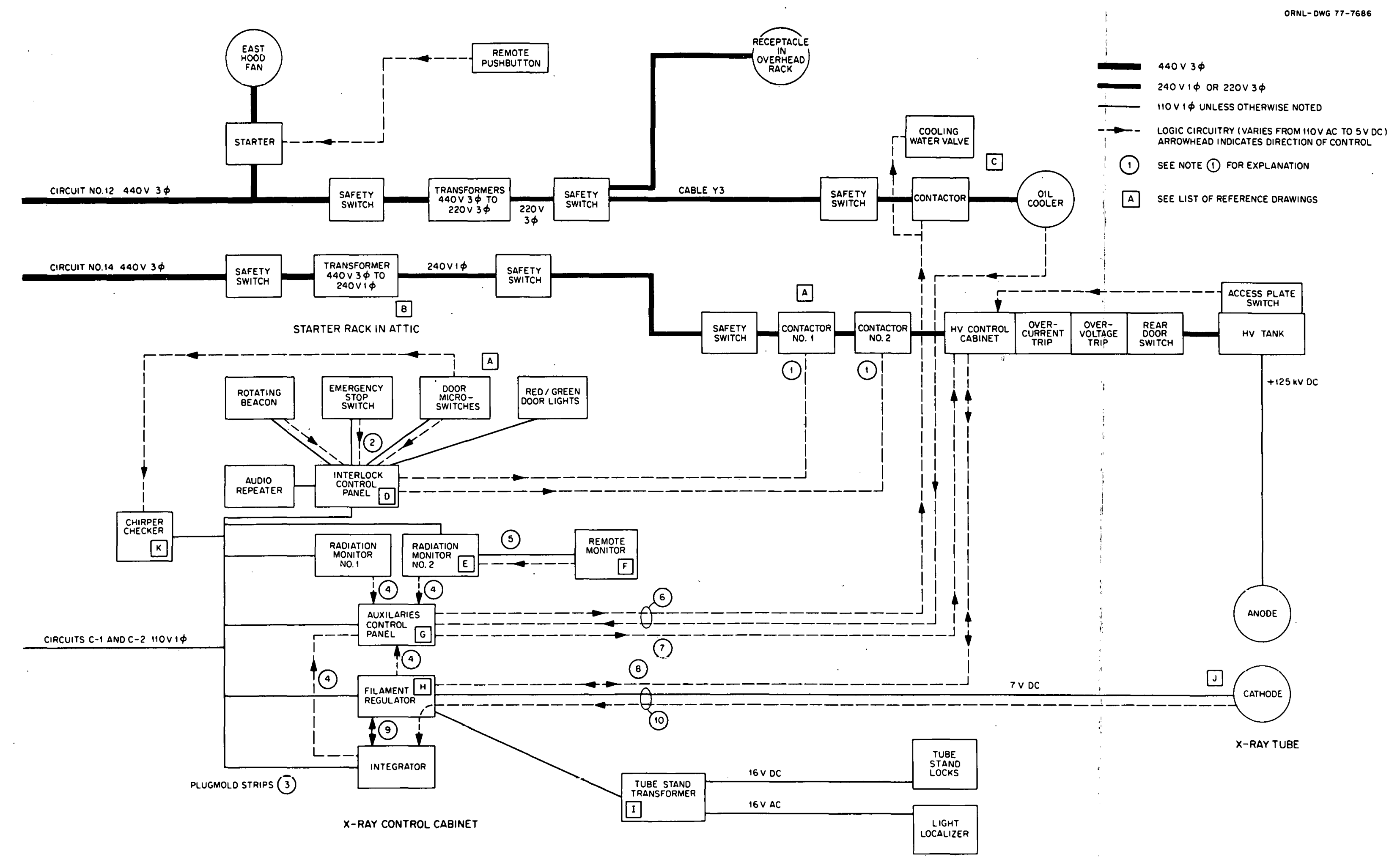

Fig. 19. Power distribution and logic schematic. 


\section{NOTES TO FIGURE 19}

1. Control of power to H.V. Cabinet via JB-1 and conduit.

2. Power to and logic signals from rotating beacon, emergency stop switch, door micro-switches, and red/green door lights via JB-1 and conduit.

3. Interlock control panel, auxillarles control panel, filament regulator panel, and integrator are powered via plug mold strips inside Main Control Cabinet. Plug mold strips get their power via $\mathrm{JB}-1$.

4. Logic signals to indicate "on" condition of Radiation Monitors, fllament regulator, and integrator Via cáblés UF, CF, Hr, and lir.

5. Remote monftor cáblès UL1, UL2, and UI.

6. $0 i 1$ cooler and water valve controlled and 011 pressure, level, and temperature sensed via FN.

7. Auxillaries Control Panel enables H.V. through AF.

8. H.V. "on" controls fllament regulator through $A G$ and integrator through $A G$ and GH2.

9. Integrator stops filament regulator via $\mathrm{GHT}$, and filament regulator stops H.V. via AG.

10. Filament is powered via GP2, and tube current is sensed through GPT. Tube current is then passed from filament regulator to the integrator via GH3.

Capital letters (e.g., DF, AF, GH2) indicate cables. See Cable Schematic Drawing ZQ-5429-1. 
LIST OF REFERENCE DRAWINGS FOR FIGURE 19

Note

\begin{tabular}{|c|c|c|}
\hline A & Conduit Plan and Elevations & $E-20130-E D-001$ \\
\hline B & Receptacle Plan and Details & $E-20130-E D-002$ \\
\hline C & $0 i 1$ Cooler Wiring & $Z Q-5429-2$ \\
\hline D & X-ray Interlock System & \\
\hline & $\begin{array}{l}\text { Interconnection and Schematic Diagram } \\
\text { Chasis Wiring }\end{array}$ & $\begin{array}{l}\mathrm{I}-20130-\mathrm{QL}-002-\mathrm{D}-3 \\
\mathrm{Q}-5219-3\end{array}$ \\
\hline$E$ & Radiation Monitor (Modified) & $2 Q-5429-11$ \\
\hline $\mathrm{F}$ & Remote Unit for Radiation Monitor & ZQ-5429-9 \\
\hline G & Auxillaries Control Panel Schematic & $Z Q-5429-3$ \\
\hline H & Tube Current Controller Schematic & $Z Q-5429-6$ \\
\hline I & Tube Stand Power Supply Circuit & $2 Q-5429-13$ \\
\hline J & X-ray Tube Cathode Adapter & $Z Q-5429-12$ \\
\hline K & $\begin{array}{l}\text { Personal Radiation Monitor Wiring } \\
\text { Diagram } \\
\text { Personal Radiation Monitor Layout }\end{array}$ & $\begin{array}{l}\text { HPD }-2447 \\
\text { HPD }-2437\end{array}$ \\
\hline
\end{tabular}


HEALTH PHYSICS AND SAFETY FEATURES

The facility has two major potentially dangerous aspects--radiation and electrical hazard. Under normal operating conditions the exposure rate at the face of the collimator can be as high as $1 \mathrm{R}$ per second. Several minutes of exposure (inadvertent or otherwise) could result in acute radiation sickness or death. Also the equipment in and around the $x$-ray facility produces or uses $110 \mathrm{~V} \mathrm{AC}, 220 \mathrm{~V}$ single-phase AC, 220V three-phase $A C, 440 \mathrm{~V}$ three-phase $A C$ and $125,000 \mathrm{~V} D C$. Any one of these sources of electric power are potentially lethal. In addition fire, chemicals, and laser light are other potential hazards.

Several physical devices (i.e., shielding, an interlock system, and warning devices) and several matters of policy and procedure (i.e., operator training, operating procedure, annual inspection, etc.) have been formed into a health physics and safety program for the $x$-ray facility in Building 2008. The aspects relating to radiation safaty are discussed first in this section, the aspects relating to other safety matters, subsequently.

\section{Radiation Safety Devices}

The principal radiation safety device in this facility is the shielding and the policy concerning it. The shielding is designed and installed to provide adequale protection from radiation to all persons outside the $x$-ray room and the attic above the $x$-ray room. The most basic matter of policy concerns the use of the shielding. This policy is that no one may be inside the $x$-ray room while the $x$-ray machine is being operated. This rule may be circumvented only with the specific 
permission of supervision and with appropriate applied health physics personnel present and monitoring the unusual activity.

The purpose of most of the physical safety devices is to ensure that the physical shielding and the policy of exclusion are employed properly. The access to the $x$-ray room and the attic above the $x$-ray room are controlled. The $x$-ray beam is controlled so that it may impinge only on the primary shield. There are warning devices inside and outside the $x$-ray room. A master key and a push button on the control panel require a "positive control" start-up. An emergency stopswitch is located inside the $x$-ray room. Personal radiation monitors (PRM's) and a device to assist in their diligent use are located near the entrance to the $x$-ray room.

Most of the active components of the health physics and safety system are coordinated by the interlock control panel. Figure 20 is a schematic drawing of the interlock system. The interlock system was designed and fabricated by the Instruments and Controls Division: of ORNL. Its design was approved by the appropriate safety committees. The system meets or exceeds all ORNL design requirements. The components of the interlock system and the other radiation safety features are described in the following paragraphs. Redundancy and indicator lights

The interlock system has two independently wired circuits that each control one of two contactors connected in series. The contactors allow the high voltage supply to be energized. The status of the key switch, the door micro-switches, and each contactor are monitored by pairs of indicator light.s. Each indicator light shows the status of its respective 


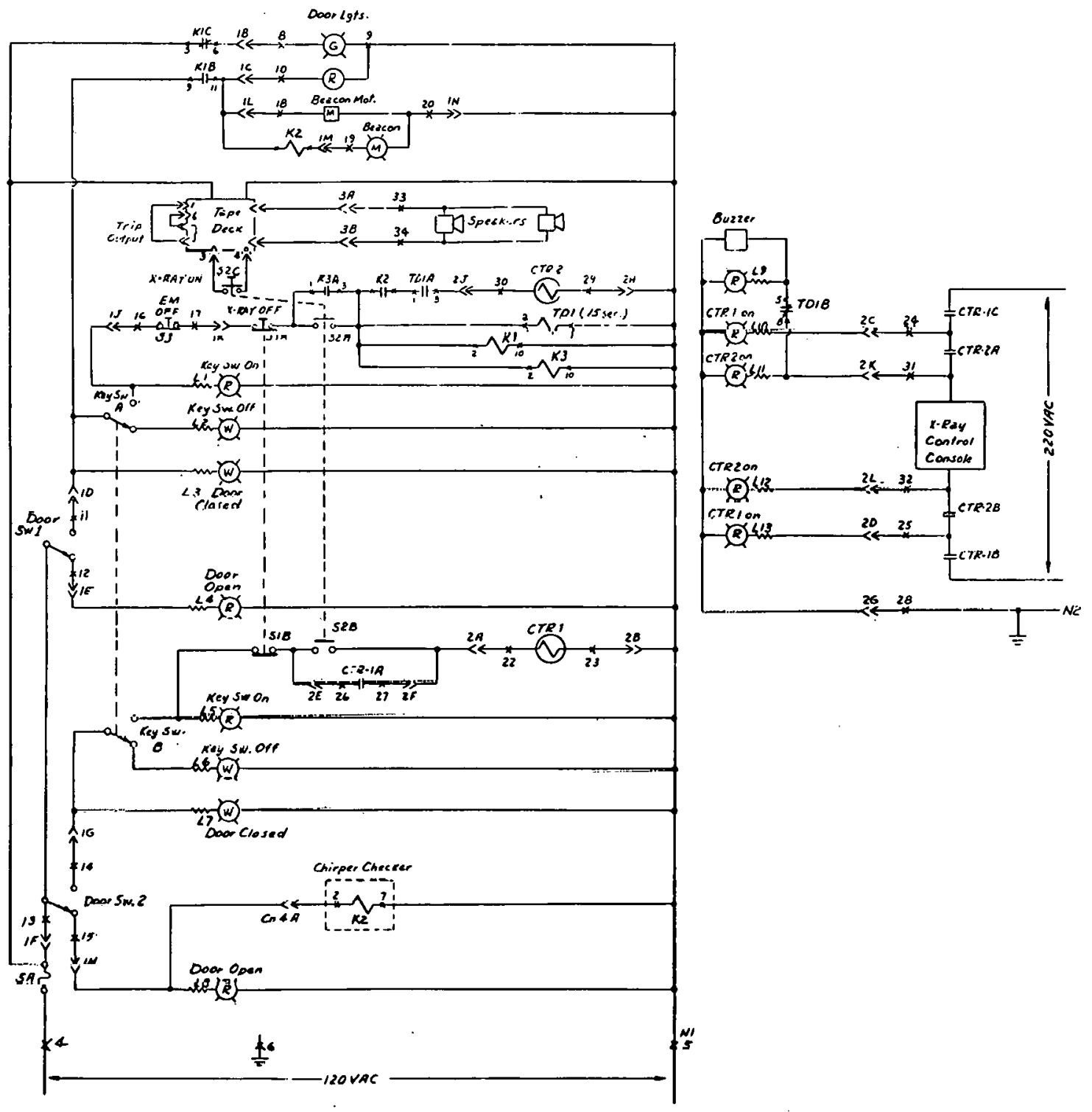

Figure 20. Interlock Systen Schenatic.

(From ORML-Orawing No. 1-20130-QL-002-0-3)

Fig. 20. Interlock system schematic. 
component with respect to one of the two circuits. Scrutiny of the order and manner in which the indicator lights are illuminated shows that the interlock system is functioning properly. The indicator lights, key switch and push buttons are arranged on the interlock control panel in a "flow chart" fashion to facilitate detection of improper operation of any component of the interlock system.

X-ray room access control

The only normal access to the $x$-ray room is a set of double doors in the secondary shield. The inactive leaf of the double door is secured with a "Kirk" type key interlock. The inactive leaf must be closed and locked before the interlock key can be removed from the door lock and inserted in the enabling lock of the interlock control panel. The active leaf of the double door is monitored by two micro-switches. Each of the independently-wired interlock circuits includes one of these micro-switches. Thus opening the $x$-ray room door would immediately disable the high voltage supply.

Attic access control

The only normal access to the attic is through a screen door and cage in the west end of Building 2008. This door is secured with a key interlock similar to the one that controls the inactive leaf of the $x$-ray room door. The trap door to the attic in the east end of Building 2008 is locked from inside the attic. $\underline{x-r a y}$ beam control

The $x$-ray beam must impinge on the primary shield. (The primary shield is outside the north wall of the $x$-ray room.) A collar and a key interlock are installed on the tube head to prevent the tube shield from 
rotating about its long axis. The collar must not be loosened or removed. Further the $x$-ray machine must not be operated unless either a collimator or treatment cone is affixed to the $x$-ray tube shield. Red/green entrance lights

A pair of lights (one red, one green) are positioned above the $x$ ray room door. The red light indicates that the $x$-ray machine is energized or is being started-up. The $x$-ray rooln should not be entered when the rod light is illuminated. The green light indicates that the $x$-ray machine is shut-down and that entrance to the $x$-ray room is permissible. One and only one of these lights should be illuminated at all times. If neither is illuminated, entry to the room is prohibited.

\section{Rotating magenta beacon}

A rotating magenta beacon is positioned near the $x$-ray machine. This beacon is illuminated during start-up and throughout the time that the high voltage supply is enabled. The continuity of the filament of the beacon is sensed by a component of the safety interlock system. Burll-uul of the fllament witl disable the high voltage supply. Audible warning

The Interlock control s.ystem causes a 30 sernnd delay during the start-up of the $x$-ray machine. During this time the interlock control system broadcasts a pre-recorded message inside the $x$-ray room and in the attlc above the $x$-ray room. The text of the message warns of the start-up of the $x$-ray machine and advises people to leave the attic and the $x$-ray room immediately. 


\section{Emergency stop switch}

A mushroom-head pushbutton is mounted on the west wall of the $x$-ray room. Momentarily depressing this button during or after the broadcasting of the audible warning will disable the high voltage.

Key protocol.

Two keys, permanently fastened to identification tags, are needed to operate the $x$-ray machine. The attic door key unlocks the door to the attic. (This key also unlocks the "Best" padlock that can be used to secure the x-ray room door.) The lock on the attic door is fitted with "Best" tumblers so that emergency personnel may enter during an emergency without delay. This key and its spare are of the Ml-38 sub-master series. The $x$-ray machine operator, the $x$-ray facility supervisor (who holds the spare), the ORNL Shift Supervisor, and the ORNL Fire Captain are the only people who should have keys that will unlock the west attic door.

The main interlock key unlocks the inactive door leaf and the tube shield interlock. This key (and its spare) are unique at ORNL. A11 replacement keys must be ordered through Commer C. Hall (I \& C Division). The $x$-ray machine operator is responsible for keeping the main interlock key in his possession or in a secure place at all times that he is not in a position to view the $x$-ray machine control console. Control of the main interlock key is the major method of preventing unauthorized (presumably ignorant and untrained) persons from operating the $x$-ray machine.

The supervisor of the $x$-ray facility shall keep all spare interlock keys. He shall ensure that only one of each interlock key is in circulation at any time. 


\section{Positive control}

After the interlock keys are in place and the $x$-ray room door is closed, the operator must activate the start switch. At the completion of the audible warning the high voltage power supply will be energized. Should the start-up sequence or the energized state be interrupted by the door micro-switches, the emergency stop, the control panel stop switch, or power failure, the operator must reactivate the start switch and complete the audible warning sequence before the $x$-ray machine can produce $x$-rays.

Warning signs

The following signs are posted in and around the $x$-ray facility. West attic door signs. "Radiation Zone" and "See operator in east end of building for key or call 3-1481. Emergency personnel notify operator upon emergency entry."

East attic trap door sign. "X-radiation. № attic entry. Use west stairs."

Outside $x$-ray room door sign. "X-radiation. Enter only with green light above."

Inside $x$-ray room door sign. "EXIT, Ōpen door to disable x-ray machine."

Signs near rotating beacon. ( 3 signs hung in a triangle) "Xradiation. X-rays produced when beacon is on."

Emergency stop switch sign. "Scram switch. Depress to disable $x$-ray machine.".

Labels on tube stand and tube shield. "Caution--X-rays. This equipment produces $x$-rays when energized." 
Signs and labels on high voltage tank (2), high voltage cable, and anode end of tube shield. "Danger. High voltage. Over 600 volts."

Signs on high voltage control console. "Radiation. This equipment produces x-rays when energized" and "Danger. High voltage. Over 600 volts." Personal radiation monitors

Two personal radiation monitors (PRM-B) are maintained for use in the $x$-ray room. Persons entering the $x$-ray room shall carry these monitors on their person.

A device to assist in the diligent use of the PRM's is located adjacent to the $x$-ray room door. This device functions as a rack for the PRM's when they are not in use. Should anyone enter the room without removing a PRM from the rack, he will be advised of his violation of policy by a buzzer and a flashing light. This device has a small radioactive gamma source attached to the side to facilitate checking of the PRM's. This device is not shown on all safety interlock drawings. Radiation monitors

The area near the control console and the laboratory immedfately to the west of the $x$-ray room are equipped with radiation monitors. These monitors must be turned on before the $x$-ray machine can be operated. They provide an audible alarm at the control panel should the radiation exposure rate in these areas exceed $0.25 \mathrm{mR} / \mathrm{hr}$. A remote readout device is positioned near the probe in the laboratory to the west. This device indicates with lights when the $x$-ray machine is enabled and when the $0.25 \mathrm{mR} / \mathrm{hr}$. limit is being exceeded. Operations $\log$

An operations log shall be maintained detailing: 
(a) when the machine was operated

(b) name of operator

(c) nature of use

(d) any information relative to the safeguards (when tested, failures, etc.)

(e) maintenance needs and maintenance work performed. 
Radiation Safety Policy and Procedures

Responsibilities of the $x$-ray machine operator

The $x$-ray machine operator shall operate the $x$-ray machine in a safe and efficient manner. He shall not change or circumvent any component of the health physics and safety program (including the shielding, the interlock system, other safety devices, and, safety policies) without the express permission of

1. the Heal th and Safety Research Division management personnel responsible for the $x$-ray facility,

2. the Health and Safety Research Division Radiation Control officer, and

3. the X-ray and Microwave Review Officer.

The operator shall not operate the $x$-ray machine if anyone is in the $x$-ray room or the attic above the $x$-ray room. Further he shall not operate the $x$-ray machine if any safety devices are inoperative, malfunctioning, or missing. He shall report any failures of the safety interlock system to the supervisor of the $x$-ray facility as soon as possible. He shall make proper entries in the operations $\log$ each time the $x$-ray machine is used.

Responsbilities of the $x$-ray facility supervisor

In this report the management personnel of the Health and Safety Research Division responsible for the $x$-ray facility is referred to as the $x$-ray facility supervisor. The $x$-ray facility supervisor shall

1. See that all $x$-ray machine operators are trained and qualified. A trained and qualified operator shall

(a) have a basic understanding of the dangers of radiation; 
(b) have read ORNL Health Physics Procedure No. 2.8 (Installation, Registration, and Operation of X-ray Equipment):

(c) have read ORNL Safety Manual No. 1.5 (Electrical Safety Guides);

(d) have read this manual; and

(e) demonstrate proficiency in operating the safety interlock system and the $x=$ ray machine.

2. Be custodian of the x-ray machine keys. The supervisor shall issue a main interlock key to qualified operators only. The supervisor shall insure that only one of each interlock key is in circulation at any time.

3. Require that the safety interlock system and other safety equipment be inspected annually. The inspection checklist for the interlock and safety equipment is attached to this report.

4. See that the operations $\log$ is maintained. 
Additional Safety Policy and Equipment

\section{Electrical safety}

The second major potential hazard in the $x$-ray facility is the electrical hazard. Proper grounding is the primary measure to provide electrical safety. All equipment powered by the various forms of electrical service within the building are grounded to the building ground. The high voltage tank, high voltage control console, main control console, and the tube stand are grounded to a separate safety ground. The safety ground consists of three $10 \mathrm{ft}$ long 3/4-inch diameter copper rods driven into the ground just outside the east wall of Building 2008. This ground is brought into the building via a 1-inch diameter copper wire and is made accessible at two heavy copper plates. One plate is near the ceiling to the left of the high voltage control console; the other is in the $x$-ray room near the floor behind the oil cooler. The various devices that house components that are part of the high voltage circuit are connected to the grounding plate via green-covered, heavy gauge copper wire. Devices employing high voltage are labeled with appropriate warning signs. No groundirig connection shall bc removed without apprnval of supervision and the appropriate electrical safety authorities.

The second important electrical safety "device" is the safe working habits of the $x$-ray machine operator. In addition, no one should work in the $x$-ray facility completely alone. If it is necessary to work in the $x$-ray room after normal working hours, arrangements can be made for a periodic check-in with the ORNL Shift Supervisor. 


\section{Fire safety}

Two fire extinguishers, one just inside the $x$-ray room door and one just outside, are available. These extinguishers are the $\mathrm{CO}_{2}$ type suitable for oil and electrical fires. They should not be moved, nor should the access to them be blocked. They are periodically inspected by ORNL Fire Department personnel.

other safety

Lasers, chemicals, and other potentially dangernus materials and devices are used in the $x$-ray facility from time to time. Appropriate safety precautions should be taken: In particular, eye protection should be worn at all times in the $x$-ray facility. Safety goggles should be available, and all personnel working in the x-ray facility should wear efther goggles or safety glasses. (For example, even the tissue-equivalent fluid used in phantoms can pose a safety hazard to the eyes because of its high alcohol content.). Care should be taken also when handling lead shielding bricks.

Other safety equipment is available. Gas masks are stored in the office adjacent to the x-ray facility. Helium-neon laser safety goggles are on hand. Radiation survey meters and safety straps for compressed gas cylinders are available on the premises. 
Summary of Heal th Physics and Safety Policy

for the X-ray Facility in Building 2008

1. No one shall be inside the $x$-ray room or the attic above the $x$-ray room while the $x$-ray machine is producing $x$ rays.

2. No changes, permanent or temporary, major or minor, shall be made in the shielding, interlock system, or other radiation safety devices without the express permission of

(a) the Health and Safety Research Division management personnel responsible for the $x$-ray facility,

(b) the Health and Safety Research Division Radiation Control Officer, AND

(c) the X-ray and Microwave Review Officer (major changes may have to be approved by an ORNL safety committee).

3. Each person entering the $x$-ray facility shall carry a Personal Radiation Monitor (PRM).

4. Only trained and authorized personnel shall operate the x-ray machine.

5. Any experiment involving sources of ionizing radiation other than the $x$-ray machine shall have prior approval of supervision and the Health and Safety Research Division Radiation Control Officer.

6. The installed safeguards shall be tested periodically to ascertain their operability.

7. Each operator shall make proper entries in the operations log each time he uses the $x$-ray machine. Proper entries shall include (a) when the machine was operated 
(b) name of operator

(c) nature of use

(d) any information relative to the safeguards (when tested, failures, etc.)

(e) maintenance needs and maintenance work performed. 


\section{OPERATING INSTRUCTIONS}

Following is a checklist of step-by-step operating instructions for the $x$-ray machine. The order in which the steps are to be done is usually important. The parenthetical references to particular figures in the "LOCATION" column indicate which figure displays the item referenced. 
Section 10. Pre-operation check-out

(Should be performed if it is no: certain that you were the last person to operate the $x$-ray machine or if any maintenance work has been performed on the $\alpha$-ray machine or its ancillary equipment.)

STEP ITEY. $\quad \begin{aligned} & \text { LOCATION } \\ & \text { (F igure) }\end{aligned}$

0.1 Polarity toard In H.V. tark.
(Fig. 9)

0.2 "Polarity" switch" H.V. control console
(Fig. 11)

0.3 "Main," "primary," F.V. control console and "control" cir- (Fig. 11) cuit breakers

0.4 "X-ray power cabinet switch"
0.5 "0il cooier safety switch" 0.6 Tube stand trans-
former toggle switch

Cn wall to left of H.V. control console (Fig. 1J) (Fig. 8) (Fig. 8i
Dbserve through lucite access panel in H.V. tank. Use flashlight. Eoard must be in positive position, i.e., the white wires on the boerd should be parallel to the words "positive" on the sign on top of the access parel. Normally this board is not moved.

Must be in fositive position.

Should be on.

Should be or.

On wall to left of the tube stand transformer

Tube stand transformer
Should te or.

Should be on.

${ }^{1}$ Note that the quotation marks indicate the item is labeled exactly as quoted. 
Section 1. Range selection

Note: "Low" range enables the $x$-ray machine to operate at generating potentials up to $75 . \mathrm{kV}$ with tube currents up to $20 \mathrm{~mA}$. "High" range enables the $x$-ray machine to operate at generating potentials between 75 to $125 \mathrm{kV}$ with tube currents up to $10 \mathrm{~mA}$.

\begin{tabular}{l|l} 
STEP ITEM & $\begin{array}{c}\text { LOCATION } \\
\text { (Figure) }\end{array}$ \\
\end{tabular}

1.1 Range board In H.V. tank (Fig. 9)

1.2 Range switch

H.V. control console (Fig. 11)

1.3 Over voltage trip H.V. control console (Fig. 11)

1.4 Over current trip H.V. control console (Fig. 11)
A. Observe range board through lucite access panel. Either "high range" board (one diagonal wire) or "low range" board (three parallel wires) must be firmly in position. The spacing of the "banana plugs" on each board allow it to be inserted firmly in only one orientation.

B. To change range, change board. Protect the high voltage oil by dusting around the access panel before removing it, by being careful not to drop extraneous material (i.e., flashlight, wing nuts, etc.) into the tank, and by wearing clean rubber gloves.

Switch should be positioned to match range board. Note: NEVER change range switch while H.V. power supply is energized.

Set red needle on voltmeter to 80 (low range) or $130 \mathrm{kV}$ (high range).

Set red needle on ammeter to $20 \mathrm{~mA}$ (low range) or $11 \mathrm{~mA}$ (high range). 
Section 2. Warm-up of auxillaries

(Should be performed if the $x$-ray machine has not been operated previously thet daj.)

$\begin{array}{ll}\text { STEP ITEM } & \text { LOCATION } \\ \text { (Figure) } & \text { INSTRUCTIONS }\end{array}$

2.1 "On-off" toggle Auxilleries control panel turn on.
switch
2.2 "Tube stanc power" Auxilleries control panel Turn on. toggle switish (Fig. 13)
2.3 0il cooler "on" Alxillaries contral panel button (Fig. 13)
2.4 "On-off" toggle Radiation monitors $\$ 1$ and switch $¥ 2$ on top of nain con:rol console (Fig. 16)

A. [epress romentarily. Observe "pressure," "temperature," and "level" indicator red lights.

B. Fun oil cooler for at least $10 \mathrm{~min}$. to fill tube shield. Manually tilt tube shield $\pm \angle 5^{\circ}$ to ensure that tube shield is full of oill.

C. Check water flow through flow meter. (Fig. 8.) Flow should register about 5 on to 100 scale. Adjust flow with value (Fig. B) if necessary.

NGTE: Steps 2.4 through 2.5 may be performed while waiting for tube shield to fill.

A. Turn on.

B. Set "integrating time" to 1 second Set "rance": to $\times 10$

NCTE: Radiation monitor \#2 requires 5 min warm-uj. During this time the needle will erroneously register up-scale. 
Section 2. Warm-up of auxillaries (cont'd)

$\begin{array}{lcc}\text { STEP } & \text { LOCATION } & \text { INEM } \\ \text { (Figure) } & \text { INTRUCTIONS }\end{array}$

$\begin{aligned} & 2.5 \text { "Function" switch Integrator (Fig. 15) } \begin{array}{l}\text { Turn to "operate," Set "polarity" to } \\ \text { "positive." }\end{array} \\ & \text { NOTE: See Model 1000C Instruction Manual } \\ & \text { for details about other controls. }\end{aligned}$

2.6 Circuit breaker Filament regulator panel (Fig. 14)
A. When oil cooler has run long enough, turn breaker on.
B. Meters on filament power supply should indicate about 1 volt and 2 amps.
C. At this point auxillaries control panel should be "all red."
NOTE: Filament power supply should not be left on for more than $10 \mathrm{~min}$. when $x$-ray machine is not being used.


Section 3. Activaie and check interlocks

NOTE: To activate interlucks foliow the procedure outlined below. Special attention should be givan to the order and manner in wicic the jights on the interloak control janel are illuminated and extinguished. The black lines drawn on the panel indicate the proper order, and each pair of lights should operate in unison. Lights lighting out of order, lights not functioning in pairs, or a suzzer sound:ns indicate failure of a component of the interlock system. In this case shut down the $x$-ray. machine immediately and notify superisision.

STEP

\section{$3.1 \quad x$-ray roor door}

3.2 Key switches

Interlock control panel (Fig. 12)

3.3 "X-ray on" push button
Interlock control sanel

(Fig. 12)
Close door and observe pair of "door closed" red indicatar lights.

Insert "main interlock" key and "attic door interlock." key. Rotate main key $1 / 2$ turn counter-clockwise. Observe pair of "key on" red indicator lights.

Depress button momentarily.

Observe: 1. The pair of "contactor 1" red indicator lights.

2. The red light above the x-ray room door.

3. The magenta beacon inside the $x$-ray room (functioning of the beacon may be observed by looking at the section of the wall above the bathroom door).

4. The broadcasting of the audible warning.

5. The energizing of "contactor 2" which should occur approximately 20 seconds after the " $x$-ray on" push button is depressed. 


\section{Section 4. High voltage initialization}

(If the $x$-ray mashine has not been run in the past hour it should be warmedup at $50 \mathrm{kV}$ (10' $\mathrm{N}$ range) or $75 \mathrm{kV}$ (high range) at a tube current of $5 \mathrm{~mA}$ for a period of 5 min.)

STEP ITEM

4.1 Indicator lights

4.2 "Range" switch and "Fine adjustment" verriier pot

4.3 "Damping adjust" knob

Filament regulator panel (Fig. 14)

4.4 Range switch

Integrator (Fig. 15)

4.5 "Preset" switch

Integrator (Fig. 15)

4.6 Preset thumbwheels Integrator (Fig. 15)

4.7 "Voltage control" knob

H.V. control console (Fig. 11)

4.8 "Kilovolts" digital H:V. control console knobs (two)
Check to see that all indicator lights on both panels are red.

Set to position to produce the approximate desired current. Note that tube current is approximately the product of the range times the fine adjustment setting divided by 10.0 .

Set to desired position. For tube currents of 2 - $20 \mathrm{~mA}$ set to $1 \mathrm{sec} ; 0.2-2.0 \mathrm{~mA}$ set to $3 \mathrm{sec}$; below $0.2 \mathrm{~mA}$ set to $10 \mathrm{sec}$.

Set to $20 \mathrm{~mA}$ scale.

Set preset to "local" for automatic shut-off or to "off" for manual shut-off.

Set to desired preset if "local" position of preset.switch is used.

Set to zero.

Set each knob to minimum. 
Section 5. Producing $\mathrm{x}$ rays

STEP

LOCATION

(Figure)

INSTRUCTIONS

5.1 H.V. - or push- H.V. control console
button
$($ Fig. 11$)$

button

5.2 "Kilovolts" digital H.V. control console knobs (two) (Fig. 11)

5.3 "Voltage control" H.V. control console knob (Fig. 11)
Depress morrentarily. Observe that the filament currert (meter on Kepso supply) increases to about $7 \mathrm{~A}$.

Set to desired generating jotential.

A. Increase until tube current (as indicated on millimeter on H.V. control console) is 15\% above the value set in step 4.2 . Wait 3 to $10 \mathrm{sec}$ and tabe current should drop to the desired amount.

B. For tube currents below $2 \mathrm{~mA}$, observe generating jotential on meter on H.V. control console and

1. Increase voltage cantrol knob slowly until further increases produce no increase in voltage. Meter will indicate a voltage near the one digitally selected in step 5.1 .

2. Advance voltage coritrol knob $5 \%$ above the "no increase" point determined above. At $60 \mathrm{kV}$ valtage control knob will be at $80 \%$; $80 \mathrm{kV}$ at $85 \% ; 100 \mathrm{kV}$ at (apfroximately) $90 \%$.

3. Igncre "not regulating" light.

NOTE: The voltage and currejt meters on H.V. control console give only an approximate indication ( $\pm 10 \%$ ) $0:$ the actual value. When froperly adjusted, the generating poteritial is determined to be \pm 0.5 kV by the digital kncbs, and the tube current is given accurately by the meter on the integrator. 
Section 5 . Producing $x$ rays (cont'd)

$\begin{array}{lll}\text { STEP ITEM } & \begin{array}{l}\text { LOCATION } \\ \text { (Figure) }\end{array} \\ \end{array}$

$\begin{array}{llll}5.4 & \text { Range switch } & \text { Integrator (Fig. 15) } & \begin{array}{l}\text { Set to desired range. Thumbwheels on the } \\ \text { integrator may be adjusted to account for } \\ \text { charge integrated during the process of } \\ \text { bringing up the high voltage. }\end{array} \\ 5.5 \text { "Fine adjust" } & \text { Filament regulator panel } & \begin{array}{l}\text { Fine adjustments to the tube current may } \\ \text { (Fig. 14) }\end{array} & \begin{array}{l}\text { be made. Use the meter on the integrator } \\ \text { as the best indication of tube current. }\end{array}\end{array}$


Section 6. Changing tube current while $x$ rays are being produced

\begin{tabular}{|c|c|c|c|}
\hline STEP & ITEM & $\begin{array}{l}\text { LOCATION } \\
\text { (Figure) }\end{array}$ & INSTRUCTIONS \\
\hline 6.1 & Range switch & Integrator (Fig. 15) & $\begin{array}{l}\text { Adjust upwards, if necessary, to avoid } \\
\text { "pegging" meter. }\end{array}$ \\
\hline 6.2 & "Damping adjust" & $\begin{array}{c}\text { Filament regulator panel } \\
\text { (Fig. 14) }\end{array}$ & Set to 10 seccnds. \\
\hline 6.3 & "Range switch" & $\begin{array}{c}\text { Filament regulaton panel } \\
\text { (Fig. 14) }\end{array}$ & $\begin{array}{l}\text { Set to new rarge pausing after each step } \\
\text { to allaw regulator to adjust. }\end{array}$ \\
\hline 6.4 & $\begin{array}{l}\text { "Voltage control" } \\
\text { knob }\end{array}$ & $\begin{array}{l}\text { H.V. control console } \\
(\text { Fig. } 11)\end{array}$ & $\begin{array}{l}\text { Adjust as per step } 5.3 \text { if necessary. Ad- } \\
\text { justing volitage control is necessary if } \\
\text { new current is below } 2 \mathrm{~mA} \text { and previous } \\
\text { current was above } 2 \mathrm{~mA} \text { or vice versa. }\end{array}$ \\
\hline 6.5 & "Range switch" & Integrator (Fig. 15: & Set to desired range. \\
\hline 6.6 & $\begin{array}{l}\text { "Fine adjust" } \\
\text { vernier pct }\end{array}$ & $\begin{array}{c}=i \text { lament reguiator Franel } \\
\text { (Fig. 14) }\end{array}$ & Adjust to praduce desired tube current. \\
\hline 6.7 & "Damping adjus:" & $\begin{array}{c}=\uparrow \text { lament regulator fanel } \\
\text { (Fig. 14) }\end{array}$ & $\begin{array}{l}\text { Adjust to mininum adequate value as in } \\
\text { step } 4.3 \text {. }\end{array}$ \\
\hline
\end{tabular}


Section 7. Changing generating potential (within high or low range)

\begin{tabular}{|c|c|c|c|}
\hline STEP & ITEM & $\begin{array}{l}\text { LOCATION } \\
\text { (Figure) }\end{array}$ & INSTRUCTIONS \\
\hline 7.1 & Range switch & Integrator (Fig. 15) & Switch to $20 \mathrm{~mA}$ range. \\
\hline 7.2 & "Voltage control" & $\begin{array}{l}\text { H.V. control console } \\
\text { (Fig. 11) }\end{array}$ & $\begin{array}{l}\text { Turn to zero. Wait for high voltage to } \\
\text { return to zero as indicated on high voltage } \\
\text { meter. }\end{array}$ \\
\hline 7.3 & $\begin{array}{l}\text { "Kilovolt" digital } \\
\text { knobs. }\end{array}$ & $\begin{array}{c}\text { H.V. control console } \\
\text { (Fig. 11) }\end{array}$ & Select new generating potential. \\
\hline 7.4 & "Voltage control" & $\begin{array}{c}\text { H.V. control console } \\
\text { (Fig. 11) }\end{array}$ & Bring up H.V. as described in step 5.3 . \\
\hline 7.5 & Range switch & Integrator (Fig. 15) & Return to proper position. \\
\hline
\end{tabular}


Sectior. $\varepsilon$. Ncrmal shut-down procedure

$\begin{array}{ll}\text { STEP ITEM } & \text { LOCATION } \\ \text { (Figure) } & \text { INSTRUCTIONS }\end{array}$

\begin{tabular}{|c|c|c|c|}
\hline 8.1 & Range switch & Integrator (Fig. 15) & Turn to $20 \mathrm{~mA}$ range. \\
\hline 8.2 & "Voltage control" & $\begin{array}{l}\text { H.V. control console } \\
\text { (Fig. 11) }\end{array}$ & Turn to zero. \\
\hline 8.3 & $\begin{array}{l}\text { "X-ray off" push } \\
\text { button }\end{array}$ & $\begin{array}{c}\text { H.V. control consol a } \\
(\text { Fig. } 1 \eta)\end{array}$ & Depress monentarily. \\
\hline 8.4 & $\begin{array}{l}\text { "Kilovol tage" } \\
\text { digital knobs }\end{array}$ & $\begin{array}{l}\text { H.V. control console } \\
\text { (Fig. 11) }\end{array}$ & Turn bath to minimum. \\
\hline 8.5 & $\begin{array}{l}\text { "X-ray of }=\text { " pust } \\
\text { button }\end{array}$ & $\begin{array}{l}\text { Interlock control panel } \\
\text { (Fig. 12) }\end{array}$ & Depress momentari1y. \\
\hline 8.6 & Key switch & $\begin{array}{l}\text { Interlock control panel } \\
\text { (Fig. 12) }\end{array}$ & $\begin{array}{l}\text { Rotate and remove "main interlock" key. One } \\
\text { may enter the } x \text {-ray room at this point. }\end{array}$ \\
\hline
\end{tabular}

If the $x$-ray machine is not to be operated in the next ten minutes, then

$\begin{array}{ccc}8.7 & \text { Circuit breaker } \quad \begin{array}{c}\text { Filament regulator panel } \\ \text { (Fig. 14) }\end{array} & \begin{array}{l}\text { Turn off. Range boards may be changed at } \\ \text { this paint. }\end{array}\end{array}$


Section 8. Normal shut-down procedure (cont'd)

\section{If the $x$-ray machine is not to be operated for the rest of the day}

\section{8 "Off" button Oil cooler section of the
auxillaries control panel}

8.9 Power switch

Radiation monitors

(Fig. 16)

8.10 "Function" switch Integrator (Fig. 15)

8.11 "Tube stand power" Auxillaries control panel toggle switch (Fig. 13)

\section{After oil cooler time delay is finished}

\subsection{Power switch}

\section{Auxillaries control panel}

(Fig. 13)

$$
\text { (Fig. 13) }
$$

Depress momentarily. Yellow "time delay" indicator light will illuminate. 0 il cooler will run for 3-5 min more to finish cooling $x$-ray tube and then automatically shut-off itself and the process water.

iTurn off both radiation monitors.

Turn to "off".

Turn off.

Turn off.

8.13 Keys

Secure "main interlock" key. Replace "attic door interlock" key in proper location. 


\section{MAINTENANCE}

At the time of preparation of this report, the high voltage oil in the high voltage tank and the $x$-ray tube head and oil cooler are to be inspected every 6 months. This service is to be performed under the programmed maintenance program of the Plant and Equipment Division. Their personnel will give the high voltage components a quick visual inspection and will draw a sample of oil to test its dielectric strength. They will report their findings to the $x$-ray machine operator or Metaholism and Dosimetry Group management.

Below is a list of people who may be contacted for maintenance and repairs. The list is given by component or problem.

Mechanical, electrical, or general physical problem. Stan R. Larkins, Plant and Equipment Division field engineer for Health Physics Division.

Filament regulator, auxillaries control panel, tube stand transformer, radiation monitors, intercoiniecliny clrcuftry, and cathode junction box (i.e., electronic problems in general). Gerald K. Schultz, Instruments and Controls Division engilieer.

Annual inspection, $x$-ray facility radiation surveys. Walter $F$. Ohnesorge, X-ray and Microwave Review Officer.

General health physics advice, personal radiation monitor mal-

function. R. D. Birkhoff, Health and Safety Research Division Radiation Control officer.

Interlock system, replacement "Kirk" keys. Comer C. Hall, Instruments and Controls Division engineer, designated interlock "expert." 
H.V. repair (oil change, etc.). William C. Fair, electrical shop foreman.

For advice or replacement parts, the following list is given.

High Voltage Unit

Universal Voltronics Corp.

27 Radio Circle Drive

Mount Kisco, NY 10549

(914) 241-1300

Sales Engineer (most helpful) - Vince Gianguzzi

UVC Mode I \#BRE-150-10-ORNL

Siemens parts (including tube stand, tube housing, $x$-ray tube, oil cooler, and cables)

Wallace X-ray Co.

109 Churchwell at Central

Knoxville, TN 37917

f (615) 524-3621

President and Chief Sales Engineer - Wallace A. Casnelli

NOTE: Five replacement bulbs for the light localizer and extra lead counter weights for the tube stand are stored in Building 2008. 


\section{THIS PAGE}

\section{WAS INTENTIONALLY LEFT BLANK}




\section{APPENDIX I - ANNUAL INSPECTION CHECKLIST}

1.0 Attic West Door (Note tumbler series number)

1.1 Mechanical integrity of door

1.2 Mechanical integrity of lock and latch

1.3 Presence and legibility of warning sign (Go through attic to east door)

\subsection{Attic East Trapdoor}

2.1 Mechanical integrity of door

2.2 Mechanical integrity of lock

2.3 Presence and legibility of warning signs

(Leave trapdoor open, return to west attic door, lock it, and go to $x$-ray room)

\section{$3.0 \quad X$-ray Room}

3.1 Mechanical integrity of inactive door lock

3.2 Presence and legibility of warning sign on $x$-ray room door

3.3 Attempt to activate interlocks with active leaf open

3.4 Mechanical integrity of $\mathrm{Pb}$ overlap on door jam and active leaf

3.5 Presence of green light over door (Close door and activate interlocks)

3.6 Presence of red light over $x$-ray room door

3.7 Audible alarm presence and clarity in attic (When audible alarm is finished, depress "stop" switch. Close east attic trapdoor and have inspector enter $x$-ray room while operator activates interlocks) 


\subsection{Function of Rotating Magenta Beacon}

4.1 Presence and legibility of beacon sign

4.2 Audible alarm presence and clarity

$\underline{4.3}$ Visibility of emergency stop switch and sign

4.4 Function of emergency stop switch (press switch and beacon should cease)

4.5 Presence of exit sign on back of $x$-ray room door (Inspector exit $x=$ ray room)

\subsection{Chirper Checker}

5.1 Check each PRM with source in PRM rark

5.2 Open $x$-ray room door without removing PRM--should get immediate buzz and flashing indicator

5.3 Close x-ray room door without removing PRM--buzz and flashing indicator should continue until PRM is removed. Remove PRM.

5.4 Replace PRM. Remove PRM. Open x-ray room door. Close x-ray room door. Wait. Buzzer should sound aftër 20 second delay and continue until PRM is replaced. Replace PRM.

\subsection{Inter lock Control Panel}

6.1 Presence and legibility of warning sign

$\underline{6.2}$ "Christmas tree" furrctiun

(nctivate interlock system and observe that the lights are activated in exactly the manner given in the operating procedure.)

6.3 Contactor function

(Remove main key and note that neither contactor light is on.) 
7.0 Beam Control

7.1 Integrity of beam control key interlock collar

7.2 Presence of collimator

8.0 Fire Extinguishers

8.1 Inside $x$-ray room

6.1.1 type (electrical and 0.11 )

8.1.2 inspection date

$\underline{8.1 .3}$ accessibility

8.2 Outside x-ray room

8.2.1 type (electrical and oil)

8.2.2 inspection date

8.2.3 accessibility

\subsection{Safety Shower}

\section{$\underline{9.1}$ Inspection}

9.2 Accessibility.

10.0 Electrical Safety

10.1 High voltage sign on transformer

10.2 Mechanical integrity of grounding strap

10.2.1 transformer

10.2.2 tube stand

11.0 Area Radiation Monitors

(Cause audible alarms to trip using a radinactive source.)

11.1 Monitor in control area

11.2 Monitor in adjacent laboratory 


\subsection{Posted Documents}

12.1 Presence of operating procedures

12.2 Audit qualified operators list

12.3 Presence of annual inspection record

12.4 Presence and completeness of operations $10 \mathrm{~g}$

\subsection{Key Control}

13.1 Count supervisor's spare keys, check against his key control records

13.2 Contact the ORNL key control officer to verify that the only keys which can open the attic door belong to the operator, supervision, the shift supervisor and the appropriate emergency personnel. 
ORNL/TM-5923

\section{INTERNAL DISTRIBUTION}

1-2. Central Research Library
3. Document Reference Section
4-6. Laboratory Records Department
7. Laboratory Records, ORNL R.C.
8. ORNL Patent Office
9. V. E. Anderson
10. J. A. Auxier
11. S. I. Auerbach
12. C. E. Bemis
13. W. F. Bunch
14. H. M. BuIter
15. D. J. Christian
16. K. E. Cowser
17. F. L. Culler
18. D. M. Davis
19. H. W. Dickson
20. M. R. Ford
21. W. R. Garrett
22. R. E. Goans
23. M. W. Good

24. F. F. Haywood

25. R. F. Hibbs

26. T. D. Jones

27. S. V. Kaye

28. G. D. Kerr

29. S. R. Larkins

30. F. D. Mundt

31. W. F. Ohnnesorje

32. W. W. Parkinson

33. S. K. Penny

34. P. T. Perdue

35-40. J. K. Poggenburg

41. H. Postma

42. C. R. Richmond

43. B. S. Shoup

44. J. B. Storer

45. J. H. Thorngate

46. G. G. Warner

47. H. A. Wright

\section{EXTERNAL DISTRIBUTION}

48. J. R. Cameron, University of Wisconsin, Department of Radiology, University Hospital, 1300 University Avenue, Madison, Wis. 53706.

49. W. L. Chen, Lung-Tan, P.O. Box 3, Taipei, Taiwan, Republic of China 325.

50. R. E. Christman, University of North Carolina at Chapel Hill, Department of Environmental Science and Engineering, School of Public Health, Chapel Hill, N. C. 27514.

51. R. J. Cloutier, ORAU, Oak Ridge, Tenn. 37830.

52. S. F. Deus, Coordenadoria de Protecáo Radiologica E Dosimetria, Instituto de Energia Atômica, Cidade Universitaria, C.P. 11049, Pinheiros, São Paulo, S.P., Brazil.

53. Director, Research and Technical Support Division, ERDA-ORO.

54. H. L. Fisher, Jr., Experimental Biology Laboratory EPA, Research Triangle Park, NC. 27711.

55. S. M. Garry, TVA-River Oaks Building, Muscle Shoals, Ala. 35660.

56. Dr. James Kereiakes, E555 Medical Sciences Building, University of Cincinnati, Cincinnati, Ohio 45267.

57. H. N. Mei, P.0. Box 3, Lung-Tan, Taiwan 325, Republic of China.

58. D. W. Moeller, 27 Wildwood Dr., Bedford, Mass. 01730.

59-60. ORAU University Programs Office, Oak Ridge, Tenn. 37830.

61. Dr. Peter Paras, Bureau of Radiological Health, Food and Drug Administration, 12720 Twinbrook Parkway, Rockville, Md. 20852.

62. J. W. Poston, Georgia Institute of Technology, School of Nuclear Engineering, Atlanta, Ga. 30332. 
63-72. M. Rosenstein, 6 Gruenther Court, Rockville, Md. 20851

73. R. S. Roswel1, c/o Andrew Rapacz, 777 McMerry \#6, Richmond, Washington.

74. B. Saylor, University of North Carolina at Chapel Hill, Department of Radiology, School of Medicine, Chapel Hill, N.C. 27514.

75. R. H. Schnieder, Bureau of Radiological Health, Food and Drug Administration, 12720 Twinbrook Parkway, Rockville, Md. 20852.

76. B. Shleien, 73 Fuller St., Brookline, Mass. 02146.

77. J. M. Siedband, University or Wiscurssln, Department of Radiology, University Hospital, 1300 University Avenue, Madison, Wis. 53706.

78-87. P. S. Stansbury, Department of Environmental Sciences and Engineering, School of Public Health, University of North Carolina at Chapel Hill, Chapel Hill, N.C. 27514.

88-114. Technical Information Center, ORO, Oak Ridge, Tenn. 37830.

115. J. E. Watson, Jr., University of North Carulirla at Chapel H111, Üepartment of Environmental Science and Engineering. Schonl of Public Health, Chapel Hill, N.C. 27514.

116. W. W. Weyzen, Radiological Physics and Instrumentation Branch, Division of Biomedical and Environmental Research, Department of Energy, Washington, D.C. 20545.

117. D. R. White, Radiation Physics Department, St. Bartholomew's Hospitali, West Smithfield, London EClA7BE, England.

118. R. W. Wood, Radiological Physics and Instrumentation Branch, Division of Biomedical and Environmental Research, Department of Energy, Washington, D.C. 20545.

119. John C. Villforth, Bureau of Radiological Health, Food and Drug Administration, 12720 Twinbrook Parkway, Rockville, Md. 21205. 